\title{
Effect of Some Agro-Management Systems on Growth and Production of Date Palm Off-Shoots under North Sinai Conditions
}

\author{
Sheren Adel Abd-ElHamied \\ Desert Research Center, Cairo, Egypt.
}

\begin{abstract}
This study was conducted during two successive seasons (2012 and 2013) at Baloza Experimental Station, Desert Research Center, North Sinai Governorate, Egypt. This research aimed to study the effect of effective microorganisms (EM) applications, and some planting media on improving rooting and growth characteristics of survived Hayany offshoots date palm cultivar in the nursery. The effective microorganisms (EM) applications were 0, 50 and $100 \mathrm{ml} / \mathrm{palm} /$ year. While, planting media were $T_{1}$ : control treatment (normal sandy soil), $T_{2}$ : mixture of cattle manure + sandy soil $(1: 2, v: v), T_{3}:$ mixture

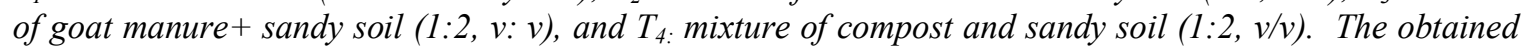
results cleared that $100 \mathrm{ml}$ of EM application was the best than other levels. Also, Hayany offshoots planted in $T_{3}$ recorded the best root performance results as compared with the other planting media. In addition, $T_{3}$ under $100 \mathrm{ml}$ EM applications produced the highest offshoots survival ratio, rooting percentages and enhanced the other growth parameters.
\end{abstract}

Key words: Date palm, Hayany date palm cultivar, planting media, effective microorganisms, offshoots, nursery, rooting.

\section{Introduction}

Date palm (Phoenix dactylifera L.) is one of the oldest fruit trees in the world. It's regard to the fruits trees of tropical and subtropical zone. However, the Middle East and North Africa are the major date palm producing areas in the world.

Successful establishment of date palm offshoots is depended on regeneration of a new root system and leaf growth. Many factors are affecting either success or failure of offshoots to establish and survive such as humidity and soil moisture.

A soil conditioner is a product which is added to soil to improve physical and chemical qualities, especially its ability to provide nutrition for plants. Soil conditioners can be used to improve poor soils to be more usable for planting or to rebuild soils which have been damaged by improper management. In addition, to maintain soils in peak condition.

Planting media repair damaged soil and help maintain the soil quality for plant life. Over time soil will become compacted. Planting media help to loosen the soil as well as replenish and maintain nutrients in order to flourish the plants. For the best result it is important to mix the soil and the soil conditioner before planting. Planting media may be containing organic matters. Organic manures improve soil physical conditions such as moisture retention, aggregate soil stability capacity, soil fertility and crop performance. (Hati et al., 2006). Organic manures are able to increase the soil microbial biomass and enhance its activity that improves the enzymatic activity in the soil (Ren et al., 1996; Sun 2003; Lv et al., 2005).

Rooting medium is important in determining the extent of root formation of date palm offshoots. The highest rooting percentages were obtained by perlite + peatmoss $(3: 1)$ medium, followed by wood shavings + peatmoss $(1: 1)$ and perlite + peatmoss $(1: 1)$. Sand medium was inferior to the others studied media (Al-Mana et al., 1996). Offshoots planting in a soil mixture of sand, peat moss, vermiculite, and perlite (1:1:1:1) gave the highest survival percentage (EL-Bahr, 2007). El- Kosary, et al., (2008) said that (Olive solid waste + sandy soil 1:2, v/v) gave the highest survival percentage and improve rooting, growth characters and mineral content of Zaghloul date palm offshoots in the nursery. In addition, Aisueni et al., (2009) said that organic manure enhances date palm growth in the nursery.

Effective microorganisms (EM) products had been in the market since 1983 in Japan (Subba Rao, 2008). Higa (1991) reported that EM contains selected species of microorganisms including three principal types, namely, lactic acid bacteria, yeast actinomyces, and photosynthetic bacteria that are commonly found in soils. Moreover, EM application increased number of the soil micro flora i.e. total bacteria, total actinomyces and total fungi which are the producers of indole acetic acid and gibberellins leads to improve growth of root system that reflected on enhancing the uptake of nutrients, thereby improving plant health under salinity stress, and consequently improve leaf mineral content (Higa, 1991). 
In addition, Effective microorganisms (EM) with organic materials can be added to the soil, to stimulate the supply and release of nutrients Jakubus et al., (2012). EM is used to improve soil fertility and plant growing conditions (Higa, 1991 and Higa and Wididana, 1991).These findings show that the use of EM compost results in richer soils that can improve growth of crops. In addition, EM application causes a distinct acceleration of organic matter mineralization in the soil, increases the volume of the root system of rootstocks and increases the growth of the assimilative surface of leaves. Zydlik P.and Zydlik Z., (2008). Adding EM to the soil increased the vegetative growth, leaf area, leaf chlorophyll and leaf mineral values( N, P, K, Fe, Zn, and Mn) as compared with the untreated Le Conte pear tree (Abd-El-Messeih et al., 2005). In addition, Osman et al. (2011) mentioned that effective microorganisms (EM) application at 1.0 $\mathrm{cm} 3 /$ palm gave the best results in growth of "Bartamuda" date palm. Moreover, El-Khawaga (2013) reported that EM application improved growth of date palm cultivars "Sewy", "Zaghloul" and "Hayany". Amro et al., (2014) mentioned that effective microorganisms (EM1) application at $90 \mathrm{ml} / \mathrm{palm}$ gave the best results in growth and leaf mineral content of "Hayany" date palm. Moreover Higa (1991) and (Higa and Wididana, 1991) Saied that enhancement effect of EM on improving growth and leaf minerals content may be attributed to the fact that EM have beneficial effect on lowering soil $\mathrm{pH}$, and increasing the uptake of water and nutrients. Formowitz et al., (2007) and Ibrahim, (2012) reported that, EM is enhancing soil fertility.

This investigation aimed to study the best concentration of EM on establishing date palm offshoots in nursery. Also, to test the most suitable planting media for increasing offshoot rooting ability and its growth performance.

\section{Materials And Methods}

This study was conducted during the two successive seasons of 2012 and 2013 at Baloza Experimental Station, Desert Research Center, North Sinai Governorate, and Egypt. Three levels of EM 0,50 and $100 \mathrm{ml} /$ palm/year adding once time by mixing EM with the planting media prior preparing offshoots for planting in both seasons.

Offshoots planting media prepared as follows: $T_{1}$ : control treatment (normal sandy soil) (Table, 1), $\mathrm{T}_{2}$ : mixture of cattle manure + sandy soil $(1: 2, \mathrm{v}: \mathrm{v}), \mathrm{T}_{3}:$ mixture of goat manure + sandy soil $(1: 2, \mathrm{v}: \mathrm{v})$ and $\mathrm{T}_{4}$ : mixture of compost and sandy soil (1:2, $\left.\mathrm{v} / \mathrm{v}\right)($ Table, 2$)$.

Hayany offshoots were planted at February of each season. Each treatment was contained 20 offshoots planted with $2 \mathrm{~m}$ between offshoots. Each 5 offshoots were dealt as one replicate and each treatment contained four replicates. Finally, each offshoot of Hayany date palm cultivar weights had ranged from 12 to $15 \mathrm{~kg}$ after preparing for planting (cleaning from old roots, dry leaves and dipping in Ferbam (Fungicide)).

Table 1: Some physical and chemical properties of the experimental soil.

\begin{tabular}{|c|c|c|c|c|c|c|c|c|c|c|c|c|c|c|}
\hline \multicolumn{3}{|c|}{$\begin{array}{c}\text { Particle size } \\
\text { distribution } \\
(\%)\end{array}$} & \multirow[t]{2}{*}{$\begin{array}{c}\text { Texture } \\
\text { soil }\end{array}$} & \multirow{2}{*}{$\begin{array}{c}\text { Ec } \\
\text { dsm }^{-1}\end{array}$} & \multirow[t]{2}{*}{ pH } & \multicolumn{5}{|c|}{$\begin{array}{c}\text { Available nutrients } \\
\text { (Cation) }\end{array}$} & \multicolumn{4}{|c|}{$\begin{array}{l}\text { Available nutrients } \\
\text { ( Anion) }\end{array}$} \\
\hline Sand & Silt & Clay & & & & $\mathbf{N} \%$ & P \% & K \% & $\begin{array}{c}\mathrm{Ca} \\
\mathrm{meg} / \mathrm{l}\end{array}$ & $\begin{array}{c}\mathrm{Mg} \\
\mathrm{meg} / \mathrm{l}\end{array}$ & $\mathrm{CO3}$ & $\begin{array}{c}\mathrm{HCO3} \\
\mathrm{meg} / \mathrm{l}\end{array}$ & $\mathrm{Cl}^{-}$ & $\begin{array}{r}\text { SO } \\
4 \\
\end{array}$ \\
\hline 90 & 5 & 5 & sandy & 1.50 & 8.20 & trace & 0.44 & 0.57 & 2.65 & 2.40 & - & 3.85 & 5.3 & 5.5 \\
\hline
\end{tabular}

Table 2: Some chemical properties of cattle manure, goat manure and compost.

\begin{tabular}{|c|c|c|c|}
\hline Properties & Cattle manure & $\begin{array}{c}\text { Goat } \\
\text { manure }\end{array}$ & $\begin{array}{c}\text { Compost } \\
\text { El Neel }\end{array}$ \\
\hline organic matter \% & 54.2 & 68.2 & 30.70 \\
\hline $\mathbf{N} \%$ & 1.23 & 2.61 & 1.66 \\
\hline $\mathbf{P} \%$ & 0.80 & 2.40 & 0.44 \\
\hline $\mathbf{K} \%$ & 0.50 & 2.70 & 1.56 \\
\hline $\mathbf{C}: \mathbf{N}$ & 14.20 & 19.00 & 18.70 \\
\hline
\end{tabular}

The following data were recorded at the first week of February of the next season i.e. 12 month of planting: offshoots survival percentage, No. of leaves, leaf length, total number of roots, root length, root diameter. Also, leaves $\mathrm{N}, \mathrm{P}, \mathrm{K}, \mathrm{Fe}, \mathrm{Zn}, \mathrm{Cu}$ and $\mathrm{Mn}$ contents were recorded as follows; total nitrogen was determined using micro-kjeldahl method according to (Huphries, 1959). Phosphorus was calorimetrically determined using ascorbic acid according to the method described by (John, 1970). Total potassium was determined using flame-Photometer according to (Brown and Lilleland 1946). $\mathrm{Fe}, \mathrm{Zn}, \mathrm{Cu}$ and $\mathrm{Mn}$ were estimated by atomic absorption spectrophotometer as described by Allan and prince (1965). Also, the percentages of increasing $\mathrm{N}, \mathrm{P}, \mathrm{K}, \mathrm{Fe}, \mathrm{Zn}, \mathrm{Cu}$ and $\mathrm{Mn}$ content were estimated and tabulated. 


\section{Statistical analysis}

The data were subjected to analysis of variance and Duncan's multiple range tests was used to differentiate means as described by Duncan (1955). The data were tabulated and statistically analyzed according to the spilt plot design (Snedecor and Cochran 1989). The percentages were transformed to the arcsine to find the binomial percentages according to (Steel and Torrie 1980).

\section{Survival percentage $\%$}

\section{Results and Discussion}

Table 3, cleared that Hayany offshoots survival percentage was insignificantly affected by the three EM applied levels in both seasons. However, high level with EM gave the best survival percentage in both seasons comparing with other concentration (66.67 and $68.67 \%$ in both seasons, respectively).

Regarding planting media effect, Hayany offshoots were affected significantly by different planting media used in both seasons. $\mathrm{T}_{3}$ (goat manure + sandy soil 1:2, v/v) produced the highest offshoots survival percentage ( 65.67 and $67.56 \%$ in the first and second seasons, respectively) comparing with other planting media used. Moreover, $\mathrm{T}_{3}$ was followed in a descending order by $\mathrm{T}_{4}, \mathrm{~T}_{2}$ and $\mathrm{T}_{1}(60.78,57.56$ and $42.56 \%$ in the first season and $62.00,59.22$ and $43.89 \%$ in the second season), respectively.

The obtained data from the interaction between EM application and planting media cleared that, $\mathrm{T}_{3}$ (goat manure+ sandy soil 1:2, v/v) with $100 \mathrm{ml}$ EM recorded the highest offshoots survival percentage (81.00 and $83.00 \%$ in the first and second seasons). However, the treatment of $0 \mathrm{ml}$ of EM with $\mathrm{T}_{1}$ recorded the lowest offshoots survival percentages (40.00\% in the first and $41.33 \%$ in the second seasons).

These results may be due to the application of animal manure to soil that decreases the $\mathrm{P}$ sorption capacity and increases the availability of $\mathrm{P}$ to plants. This is thought to be result from the cumulative effects of various processes. These processes may include, for example, an increase in soil $\mathrm{pH}$, blockage of $\mathrm{P}$ sorption sites by organic products released from the decomposing organic materials and complexation of toxic metal ions (e.g. Mn and Fe) by organic acids ( (Easterwood and Sartain, 1990 ; Hue, 1992; Haynes and Mokolobate, 2001). The immobilization of $\mathrm{P}$ by soil microbial biomass in response to added manure may also increase its availability to plants (Ayaga et al., 2006; Iyamuremye et al., 1996). Moreover, EM application increased number of the soil micro flora i.e. total bacteria, total actinomyces and total fungi which are the producers of indole acetic acid and gibberellins leads to improve growth of root system that reflected on enhancing the uptake of nutrients, thereby improving plant health under salinity stress, and consequently improve leaf mineral content (Higa, 1991).

The obtained results are in agreement with, (Al-Mana et al., 1996) who found that the highest rooting percentages were obtained by deferent planting media. In addition, El-Bahr (2007) who found that offshoots planting in a soil mixture of sand, peat moss, vermiculite and perlite $(1: 1: 1: 1)$ gave the highest survival percentage. El- Kosary, et al., (2008) El- Kosary, et al., (2008) who added that the planting media affected significantly on survival percentage of Zaghloul date palm cultivar in the nursery. El-Khawaga (2013) reported that EM application improved growth of date palm cultivars "Sewy", "Zaghloul" and "Hayany". Amro et al. (2014) mentioned that the effective microorganisms (EM) application at $90 \mathrm{ml} / \mathrm{palm}$ gave the best results in growth and leaf mineral content of "Hayany"date palm. 
Table 3: Effect of EM application and different planting media on survival percentage (\%) of Hayany date palm offshoots during 2012 and 2013 seasons.

\begin{tabular}{|c|c|c|c|}
\hline \multirow{2}{*}{\multicolumn{2}{|c|}{ Treatments }} & \multicolumn{2}{|c|}{ Survival percentage $\%$} \\
\hline & & Season 2012 & Season 2013 \\
\hline \multicolumn{4}{|c|}{ Effect of EM application } \\
\hline \multicolumn{2}{|l|}{$0 \mathrm{ml}$} & $47.75 \mathrm{c}$ & $48.92 \mathrm{c}$ \\
\hline \multicolumn{2}{|l|}{$50 \mathrm{ml}$} & $55.50 \mathrm{~b}$ & $56.92 b$ \\
\hline \multicolumn{2}{|l|}{$100 \mathrm{ml}$} & $66.67 \mathrm{a}$ & $68.67 \mathrm{a}$ \\
\hline \multicolumn{4}{|c|}{ Effect of planting media * } \\
\hline \multicolumn{2}{|l|}{$\mathrm{T}_{1}$} & $42.56 \mathrm{~d}$ & $43.89 \mathrm{~d}$ \\
\hline \multicolumn{2}{|l|}{$\mathrm{T}_{2}$} & $57.56 \mathrm{c}$ & $59.22 \mathrm{c}$ \\
\hline \multicolumn{2}{|l|}{$\mathrm{T}_{3}$} & $65.67 \mathrm{a}$ & $67.56 \mathrm{a}$ \\
\hline \multicolumn{2}{|l|}{$\mathrm{T}_{4}$} & $60.78 b$ & $62.00 \mathrm{~b}$ \\
\hline \multicolumn{4}{|c|}{ Effect of interaction between EM application and planting media } \\
\hline \multirow{2}{*}{ EM application } & \multirow{2}{*}{ planting media * } & \multicolumn{2}{|c|}{ Survival percentage $\%$} \\
\hline & & Season 2012 & Season 2013 \\
\hline \multirow{4}{*}{$0 \mathrm{ml}$} & $\mathrm{T}_{1}$ & $40.00 \mathrm{i}$ & $41.33 \mathrm{k}$ \\
\hline & $\mathrm{T}_{2}$ & $47.00 \mathrm{~g}$ & 49.00hi \\
\hline & $\mathrm{T}_{3}$ & $53.33 \mathrm{f}$ & $54.33 \mathrm{~g}$ \\
\hline & $\mathrm{T}_{4}$ & $50.67 \mathrm{f}$ & $51.00 \mathrm{~h}$ \\
\hline \multirow{4}{*}{$50 \mathrm{ml}$} & $\mathrm{T}_{1}$ & $43.33 \mathrm{~h}$ & $44.00 \mathrm{jk}$ \\
\hline & $\mathrm{T}_{2}$ & $56.67 \mathrm{e}$ & $57.67 \mathrm{f}$ \\
\hline & $\mathrm{T}_{3}$ & $62.67 \mathrm{~d}$ & $65.33 \mathrm{~d}$ \\
\hline & $\mathrm{T}_{4}$ & $59.33 \mathrm{e}$ & $60.67 \mathrm{e}$ \\
\hline \multirow{4}{*}{$100 \mathrm{ml}$} & $\mathrm{T}_{1}$ & $44.33 \mathrm{gh}$ & $46.33 \mathrm{ij}$ \\
\hline & $\mathrm{T}_{2}$ & $69.00 \mathrm{c}$ & $71.00 \mathrm{c}$ \\
\hline & $\mathrm{T}_{3}$ & $81.00 \mathrm{a}$ & $83.00 \mathrm{a}$ \\
\hline & $\mathrm{T}_{4}$ & $72.33 b$ & $74.33 \mathrm{~b}$ \\
\hline
\end{tabular}

\section{Rooting parameters (length, diameter and number)}

Data presented in Table 4 revealed that all studied root parameters were significantly affected by all treatments in both seasons. It is obvious that adding EM with high level to the soil increased rooting parameters in both seasons.

Planting media were also significantly affected the same rooting parameters mentioned before in both seasons. $\mathrm{T}_{3}$ (goat manure + sandy soil 1:2, v/v) produced the highest offshoots roots length (35.11 in the $1^{\text {st }}$ and $35.56(\mathrm{~cm})$ in the $2^{\text {nd }}$ season $)$, roots diameter $\left(0.84\right.$ in the $1^{\text {st }}$ and $0.87(\mathrm{~mm})$ in the $2^{\text {nd }}$ seasons $)$ and roots number (41.79 in the $1^{\text {st }}$ and 42.11 in the $2^{\text {nd }}$ seasons) comparing with other planting media used.

The interaction between EM application and planting media cleared that, $\mathrm{T}_{3}$ (goat manure + sandy soil 1:2, v/v) with $100 \mathrm{ml}$ EM recorded the highest offshoots rooting parameters roots length $(45.00(\mathrm{~cm})$ in the both seasons), roots diameter $\left(1.03\right.$ in the $1^{\text {st }}$ and $1.07(\mathrm{~mm})$ in the $2^{\text {nd }}$ seasons $)$ and roots number $(60.00$ in the $1^{\text {st }}$ and 61.00 in the $2^{\text {nd }}$ seasons). However, under $0 \mathrm{ml}$ of EM with $\mathrm{T}_{1}$ recorded the lowest offshoots rooting parameters, roots length $(16.00$ and $17.33(\mathrm{~cm})$ in the first and second seasons, respectively) roots diameter $\left(0.31\right.$ and $0.33(\mathrm{~mm})$ in the first and second seasons, respectively) and roots number $\left(5.33\right.$ in the $1^{\text {st }}$ and 5.00 in the $2^{\text {nd }}$ seasons).

The increase of roots system volume and improving growth of data parameter could be due to the application organic matter mineralization caused by EM treatments that applied in the soil Zydlik P.and Zydlik Z., (2008).

These results paralleled with those Al-Mana et al., (1996) who proved that the highest rooting percentages affected by the difference of planting media, and with El- Kosary, et al., (2008) who added that the planting media affected significantly on root length, root diameter and roots number of Zaghloul date palm cultivar in the nursery. In addition, Amro et al., (2014) mentioned that effective microorganisms (EM) application at $90 \mathrm{ml} /$ palm gave the best results in growth of "Hayany" date palm. 
Table 4: Effect of EM application and different planting media on length, diameter and number of roots of Hayany date palm offshoots during 2012 and 2013 seasons.

\begin{tabular}{|c|c|c|c|c|c|c|c|}
\hline \multirow{2}{*}{\multicolumn{2}{|c|}{ Treatments }} & \multicolumn{2}{|c|}{ Root length $(\mathrm{cm})$} & \multicolumn{2}{|c|}{ Root diameter $(\mathrm{mm})$} & \multicolumn{2}{|c|}{ Roots number } \\
\hline & & $\begin{array}{c}\text { Season } \\
2012 \\
\end{array}$ & $\begin{array}{c}\text { Season } \\
2013 \\
\end{array}$ & $\begin{array}{c}\text { Season } \\
2012 \\
\end{array}$ & $\begin{array}{c}\text { Season } \\
2013 \\
\end{array}$ & $\begin{array}{c}\text { Season } \\
2012 \\
\end{array}$ & $\begin{array}{c}\text { Season } \\
2013 \\
\end{array}$ \\
\hline \multicolumn{8}{|c|}{ Effect of EM application } \\
\hline \multicolumn{2}{|c|}{$0 \mathrm{ml}$} & $20.33 \mathrm{c}$ & $21.75 \mathrm{c}$ & $0.56 \mathrm{c}$ & $0.57 \mathrm{c}$ & $18.42 \mathrm{c}$ & $17.67 \mathrm{c}$ \\
\hline \multicolumn{2}{|l|}{$50 \mathrm{ml}$} & $28.33 \mathrm{~b}$ & $27.75 b$ & $0.68 \mathrm{~b}$ & $0.70 \mathrm{~b}$ & $26.83 b$ & $27.17 \mathrm{~b}$ \\
\hline \multicolumn{2}{|l|}{$100 \mathrm{ml}$} & $35.67 \mathrm{a}$ & $35.58 \mathrm{a}$ & $0.83 \mathrm{a}$ & $0.85 \mathrm{a}$ & $39.00 \mathrm{a}$ & $39.00 \mathrm{a}$ \\
\hline \multicolumn{8}{|c|}{ Effect of planting media * } \\
\hline \multicolumn{2}{|c|}{$\mathrm{T}_{1}$} & $17.22 \mathrm{~d}$ & $18.22 \mathrm{~d}$ & $0.41 \mathrm{~d}$ & $0.43 \mathrm{~d}$ & $7.22 \mathrm{~d}$ & $7.00 \mathrm{~d}$ \\
\hline \multicolumn{2}{|l|}{$\mathrm{T}_{2}$} & $28.89 \mathrm{c}$ & $28.22 \mathrm{c}$ & $0.73 c$ & $0.73 \mathrm{c}$ & $29.44 \mathrm{c}$ & $29.33 \mathrm{c}$ \\
\hline \multicolumn{2}{|l|}{$\mathrm{T}_{3}$} & $35.11 \mathrm{a}$ & $35.56 \mathrm{a}$ & $0.84 \mathrm{a}$ & $0.87 \mathrm{a}$ & $41.79 \mathrm{a}$ & $42.11 \mathrm{a}$ \\
\hline \multicolumn{2}{|l|}{$\mathrm{T}_{4}$} & $31.22 \mathrm{~b}$ & $31.44 \mathrm{~b}$ & $0.78 \mathrm{~b}$ & $0.79 \mathrm{~b}$ & $33.89 \mathrm{~b}$ & $33.33 \mathrm{~b}$ \\
\hline \multicolumn{8}{|c|}{ Effect of interaction between EM application and planting media } \\
\hline \multirow{2}{*}{$\begin{array}{c}\text { EM } \\
\text { application }\end{array}$} & \multirow[b]{2}{*}{ planting media * } & \multicolumn{2}{|c|}{ Root length $(\mathrm{cm})$} & \multicolumn{2}{|c|}{ Root diameter (mm) } & \multicolumn{2}{|c|}{ Roots number } \\
\hline & & $\begin{array}{c}\text { Season } \\
2012 \\
\end{array}$ & $\begin{array}{c}\text { Season } \\
2013 \\
\end{array}$ & $\begin{array}{c}\text { Season } \\
2012 \\
\end{array}$ & $\begin{array}{c}\text { Season } \\
2013 \\
\end{array}$ & $\begin{array}{c}\text { Season } \\
2012 \\
\end{array}$ & $\begin{array}{c}\text { Season } \\
2013 \\
\end{array}$ \\
\hline \multirow{4}{*}{$0 \mathrm{ml}$} & $\mathrm{T}_{1}$ & $16.00 \mathrm{j}$ & $17.33 \mathrm{j}$ & 0.311 & $0.33 \mathrm{i}$ & $5.33 \mathrm{j}$ & 5.001 \\
\hline & $\mathrm{T}_{2}$ & $19.67 \mathrm{hi}$ & $20.67 \mathrm{~h}$ & $0.59 \mathrm{i}$ & $0.59 \mathrm{f}$ & $17.67 \mathrm{~h}$ & $16.67 \mathrm{i}$ \\
\hline & $\mathrm{T}_{3}$ & $24.67 \mathrm{~g}$ & $26.33 \mathrm{f}$ & $0.69 \mathrm{~g}$ & $0.70 \mathrm{e}$ & $27.00 \mathrm{f}$ & $26.33 \mathrm{~g}$ \\
\hline & $\mathrm{T}_{4}$ & $21.00 \mathrm{~h}$ & $22.67 \mathrm{~g}$ & $0.64 \mathrm{~h}$ & $0.64 \mathrm{f}$ & $23.67 \mathrm{~g}$ & $22.67 \mathrm{~h}$ \\
\hline \multirow{4}{*}{$50 \mathrm{ml}$} & $\mathrm{T}_{1}$ & $17.00 \mathrm{j}$ & $18.00 \mathrm{ij}$ & $0.41 \mathrm{k}$ & $0.45 \mathrm{~h}$ & 7.00ij & $7.00 \mathrm{k}$ \\
\hline & $\mathrm{T}_{2}$ & $29.00 \mathrm{f}$ & $26.67 f$ & $0.72 \mathrm{f}$ & $0.73 \mathrm{e}$ & $29.33 \mathrm{f}$ & $29.33 \mathrm{f}$ \\
\hline & $\mathrm{T}_{3}$ & $35.67 \mathrm{~d}$ & $35.33 \mathrm{~d}$ & $0.82 \mathrm{~d}$ & $0.83 \mathrm{~cd}$ & $38.33 d$ & $39.00 \mathrm{~d}$ \\
\hline & $\mathrm{T}_{4}$ & $31.67 \mathrm{e}$ & $31.00 \mathrm{e}$ & $0.78 \mathrm{e}$ & $0.80 \mathrm{~d}$ & $32.67 \mathrm{e}$ & $33.33 \mathrm{e}$ \\
\hline \multirow{4}{*}{$100 \mathrm{ml}$} & $\mathrm{T}_{1}$ & $18.67 \mathrm{i}$ & 19.33hi & $0.50 \mathrm{j}$ & $0.52 \mathrm{~g}$ & $9.33 \mathrm{i}$ & $9.00 \mathrm{j}$ \\
\hline & $\mathrm{T}_{2}$ & $38.00 \mathrm{c}$ & $37.33 \mathrm{c}$ & $0.87 \mathrm{c}$ & $0.88 \mathrm{bc}$ & $41.33 c$ & $42.00 \mathrm{c}$ \\
\hline & $\mathrm{T}_{3}$ & $45.00 \mathrm{a}$ & $45.00 \mathrm{a}$ & $1.03 \mathrm{a}$ & $1.07 \mathrm{a}$ & $60.00 \mathrm{a}$ & $61.00 \mathrm{a}$ \\
\hline & $\mathrm{T}_{4}$ & $41.00 \mathrm{~b}$ & $40.67 b$ & $0.93 b$ & $0.93 b$ & $45.33 b$ & $44.00 \mathrm{~b}$ \\
\hline
\end{tabular}

\section{Leaf length and leaves number}

Data presented in Table 5 revealed that leaf length and leaves number were significantly affected by all treatments in both seasons. It is obvious that adding EM with high level to the soil increased leaflength and leaves number in both seasons.

Planting media were also significantly affected the same parameters, leaf length and leaves number mentioned before in both seasons. $\mathrm{T}_{3}$ (goat manure + sandy soil 1:2, v/v) produced the highest offshoots leaf length ( 163.33 in the $1^{\text {st }}$ and $160.78 \mathrm{~cm}$ in the $2^{\text {nd }}$ seasons) and leaves number $\left(4.78\right.$ in the $1^{\text {st }}$ and 4.44 in the $2^{\text {nd }}$ seasons) as comparing with other soil planting media.

The interaction between EM application and planting media cleared that, $\mathrm{T}_{3}$ (goat manure + sandy soil 1:2, v/v) with $100 \mathrm{ml}$ EM recorded the highest offshoots leaf length $\left(204.00\right.$ in the $1^{\text {st }}$ and $200.00 \mathrm{~cm}$ in the $2^{\text {nd }}$ seasons) and leaves number (6.33 in the $1^{\text {st }}$ and 6.00 in the $2^{\text {nd }}$ seasons). However, under $0 \mathrm{ml}$ of EM with $T_{1}$ gave the lowest offshoots leaf length $\left(100.00\right.$ in the $1^{\text {st }}$ and $99.67 \mathrm{~cm}$ in the $2^{\text {nd }}$ seasons $)$ and leaves number ( 2.00 in the both seasons) was recorded.

Adding animal manure to soil decreases the $\mathrm{P}$ sorption capacity and increases the availability of $\mathrm{P}$ to plants. This is thought to result from the cumulative effects of various processes. These processes may include, for example, an increase in soil $\mathrm{pH}$, blockage of $\mathrm{P}$ sorption sites by organic products released from the decomposing organic materials and complication of toxic metal ions (e.g. Mn and Fe) by organic acids ( (Easterwood and Sartain, 1990; Hue, 1992; Haynes and Mokolobate, 2001). The immobilization of $P$ by soil microbial biomass in response to added manure may also increase its availability to plants (Ayaga et al., 2006; Iyamuremye et al., 1996). Moreover, EM application increased number of the soil microflora i.e. total bacteria, total actinomyces and total fungi which are the producers of indole acetic acid and gibberellins leads to improvement growth of root system that reflected on enhanced the uptake of nutrients, thereby improving plant health under salinity stress consequently improved leaf mineral content (Higa, 1991). Moreover, the application of EM improving growth and leaf minerals content may be attributed to the fact that EM have beneficial effect on lowering soil $\mathrm{pH}$, and increasing the uptake of water and nutrients (Higa, 1991; Higa and Wididana, 1991), and enhancing soil fertility (Formowitz et al., 2007 and Ibrahim, 2012). 
These results are parallel with El- Kosary, et al., (2008) who added the planting media affected significantly on leaf length and leaves number of Zaghloul date palm cultivar in the nursery. EM application caused a distinct acceleration of organic matter mineralization in the soil and increased the growth of the assimilative surface of leaves Zydlik P.and Zydlik Z., (2008). In addition, Osman et al., (2011) mentioned that the effective microorganisms (EM) application at $1.0 \mathrm{~cm} 3 /$ palm gave the best results in growth of "Bartamuda" date palm. Moreover, El-Khawaga (2013) reported that EM application improved growth of date palm cultivars "Sewy", "Zaghloul" and "Hayany". Amro et al., (2014) mentioned that the effective microorganisms (EM) application at $90 \mathrm{ml} /$ palm gave the best results in growth of "Hayany" date palm.

Table 5: Effect of EM application and different planting media on leaf length and leaves number of Hayany date palm offshoots during 2012 and 2013 seasons.

\begin{tabular}{|c|c|c|c|c|c|}
\hline \multirow{2}{*}{\multicolumn{2}{|c|}{ Treatments }} & \multicolumn{2}{|c|}{ leaf length $(\mathrm{cm})$} & \multicolumn{2}{|c|}{ leaves number } \\
\hline & & $\begin{array}{c}\text { Season } \\
2012 \\
\end{array}$ & $\begin{array}{c}\text { Season } \\
2013 \\
\end{array}$ & $\begin{array}{c}\text { Season } \\
2012 \\
\end{array}$ & $\begin{array}{c}\text { Season } \\
2013 \\
\end{array}$ \\
\hline \multicolumn{6}{|c|}{ Effect of EM application } \\
\hline \multicolumn{2}{|l|}{$0 \mathrm{ml}$} & $114.08 \mathrm{c}$ & $113.17 \mathrm{c}$ & $2.75 \mathrm{c}$ & $2.67 \mathrm{c}$ \\
\hline \multicolumn{2}{|l|}{$50 \mathrm{ml}$} & $137.58 b$ & $137.50 \mathrm{~b}$ & $3.58 \mathrm{~b}$ & $3.50 \mathrm{~b}$ \\
\hline \multicolumn{2}{|l|}{$100 \mathrm{ml}$} & $167.42 \mathrm{a}$ & $166.42 \mathrm{a}$ & $4.75 \mathrm{a}$ & $4.50 \mathrm{a}$ \\
\hline \multicolumn{6}{|c|}{ Effect of planting media * } \\
\hline \multicolumn{2}{|l|}{$\mathrm{T}_{1}$} & $104.11 \mathrm{~d}$ & $103.67 d$ & $2.11 \mathrm{c}$ & $2.11 \mathrm{c}$ \\
\hline \multicolumn{2}{|l|}{$\mathrm{T}_{2}$} & $139.78 \mathrm{c}$ & $140.00 \mathrm{c}$ & $3.78 \mathrm{~b}$ & $3.67 \mathrm{~b}$ \\
\hline \multicolumn{2}{|l|}{$\mathrm{T}_{3}$} & $163.33 \mathrm{a}$ & $160.78 \mathrm{a}$ & $4.78 \mathrm{a}$ & $4.44 \mathrm{a}$ \\
\hline \multicolumn{2}{|l|}{$\mathrm{T}_{4}$} & $151.56 \mathrm{~b}$ & $151.67 \mathrm{~b}$ & $4.11 \mathrm{~b}$ & $4.00 \mathrm{~b}$ \\
\hline \multicolumn{6}{|c|}{ Effect of interaction between EM application and planting media } \\
\hline \multirow[b]{2}{*}{ EM application } & \multirow[b]{2}{*}{ planting media * } & \multicolumn{2}{|c|}{ leaf length $(\mathrm{cm})$} & \multicolumn{2}{|c|}{ leaves number } \\
\hline & & $\begin{array}{c}\text { Season } \\
2012 \\
\end{array}$ & $\begin{array}{c}\text { Season } \\
2013 \\
\end{array}$ & $\begin{array}{c}\text { Season } \\
2012 \\
\end{array}$ & $\begin{array}{c}\text { Season } \\
2013 \\
\end{array}$ \\
\hline \multirow{4}{*}{$0 \mathrm{ml}$} & $\mathrm{T}_{1}$ & 100.001 & 99.671 & $2.00 \mathrm{~h}$ & $2.00 \mathrm{~h}$ \\
\hline & $\mathrm{T}_{2}$ & $113.33 \mathrm{i}$ & $112.33 \mathrm{i}$ & $2.67 \mathrm{fgh}$ & $2.67 \mathrm{fg}$ \\
\hline & $\mathrm{T}_{3}$ & $124.33 \mathrm{~g}$ & $122.33 \mathrm{~g}$ & $3.33 \mathrm{def}$ & $3.00 \mathrm{f}$ \\
\hline & $\mathrm{T}_{4}$ & $118.67 \mathrm{~h}$ & $118.33 \mathrm{~h}$ & $3.00 \mathrm{efg}$ & $3.00 \mathrm{f}$ \\
\hline \multirow{4}{*}{$50 \mathrm{ml}$} & $\mathrm{T}_{1}$ & $104.00 \mathrm{k}$ & $103.00 \mathrm{k}$ & $2.00 \mathrm{~h}$ & $2.00 \mathrm{~h}$ \\
\hline & $\mathrm{T}_{2}$ & $133.00 \mathrm{f}$ & $134.00 \mathrm{f}$ & $3.67 \mathrm{de}$ & $3.67 \mathrm{e}$ \\
\hline & $\mathrm{T}_{3}$ & $161.67 \mathrm{~d}$ & $160.00 \mathrm{~d}$ & $4.67 \mathrm{bc}$ & $4.33 \mathrm{~cd}$ \\
\hline & $\mathrm{T}_{4}$ & $151.67 \mathrm{e}$ & $153.00 \mathrm{e}$ & $4.00 \mathrm{~cd}$ & 4.00de \\
\hline \multirow{4}{*}{$100 \mathrm{ml}$} & $\mathrm{T}_{1}$ & $108.33 \mathrm{j}$ & $108.33 \mathrm{j}$ & $2.33 \mathrm{gh}$ & $2.33 \mathrm{gh}$ \\
\hline & $\mathrm{T}_{2}$ & $173.00 \mathrm{c}$ & $173.67 \mathrm{c}$ & $5.00 \mathrm{~b}$ & $4.67 b c$ \\
\hline & $\mathrm{T}_{3}$ & $204.00 \mathrm{a}$ & $200.00 \mathrm{a}$ & $6.33 \mathrm{a}$ & $6.00 \mathrm{a}$ \\
\hline & $\mathrm{T}_{4}$ & $184.33 \mathrm{~b}$ & $183.67 \mathrm{~b}$ & $5.33 b$ & $5.00 \mathrm{~b}$ \\
\hline
\end{tabular}

\section{Leaf nitrogen, phosphorus and potassium content (g/100g.D.W)}

Data in Table 6, 7 and 8 showed significantly increased in leaf nitrogen, phosphorus and potassium content at 12 month of planting in both seasons. However, EM with high level raised significantly the rate of $\mathrm{N}$ content (16.67 in the $1^{\text {st }}$ and $16.83 \%$ in the $2^{\text {nd }}$ seasons), $\mathrm{P}$ content (13.75 and $14.42 \%$ in the first and second seasons, respectively) and $\mathrm{K}$ content $\left(20.75\right.$ in the $1^{\mathrm{s}}$ and $20.58 \%$ in the $2^{\text {nd }}$ seasons.

In addition, leaf nitrogen, phosphorus and potassium content was affected significantly by different planting media used in both seasons. It was clearly noticed that $\mathrm{T}_{3}$ increased both of nitrogen, phosphorus and potassium content and rate of increase of nitrogen, phosphorus and potassium comparing with other soil treatments used in both seasons.

The interaction between EM application and planting media showed that, $\mathrm{T}_{3}$ with high level of EM application was the best treatments that produced the highest nitrogen, phosphorus and potassium content and the rate of $\mathrm{N}, \mathrm{P}$ and $\mathrm{K}$ in offshoots leaves comparing with other interactions used in both seasons.

Generally, these results are in agreement with (Abd-El-Messeih et al., 2005) how recorded that adding EM to the soil increased the leaf mineral values; N, P and K as compared with the untreated Le Conte pear tree. In addition, El- Kosary, et al., (2008) who added that the planting media affected significantly on leaf mineral content of Zaghloul date palm cultivar in the nursery. Elias et al,. (2009) added the application of goat manure to soil could also improve the availability of $P$ through enhanced 
biological cycling of soil and fertilizer P. Jakubus et al., (2012) said that effective microorganisms (EM) with organic materials can be added to the soil to stimulate the supply and release of nutrients.

Table 6: Effect of EM application and different planting media on leaf nitrogen content (\%) of Hayany date palm offshoots during 2012 and 2013 seasons.

\begin{tabular}{|c|c|c|c|c|c|c|c|}
\hline \multirow{3}{*}{\multicolumn{2}{|c|}{ Treatments }} & \multicolumn{6}{|c|}{ Leaves nitrogen content (\%) } \\
\hline & & \multicolumn{2}{|c|}{ at planting } & \multicolumn{2}{|c|}{ at 12 month } & \multicolumn{2}{|c|}{ Increasing rate } \\
\hline & & $\begin{array}{l}\text { Season } \\
2012 \\
\end{array}$ & $\begin{array}{l}\text { Season } \\
2013 \\
\end{array}$ & $\begin{array}{l}\text { Season } \\
2012 \\
\end{array}$ & $\begin{array}{l}\text { Season } \\
2013 \\
\end{array}$ & $\begin{array}{l}\text { Season } \\
2012 \\
\end{array}$ & $\begin{array}{l}\text { Season } \\
2013 \\
\end{array}$ \\
\hline \multicolumn{8}{|c|}{ Effect of EM application } \\
\hline \multicolumn{2}{|l|}{$0 \mathrm{ml}$} & $1.61 \mathrm{a}$ & $1.61 \mathrm{a}$ & $1.68 \mathrm{c}$ & $1.67 \mathrm{c}$ & $6.83 c$ & $6.75 \mathrm{c}$ \\
\hline \multicolumn{2}{|l|}{$50 \mathrm{ml}$} & $1.61 \mathrm{a}$ & $1.61 \mathrm{a}$ & $1.72 \mathrm{~b}$ & $1.70 \mathrm{~b}$ & $11.00 \mathrm{~b}$ & $9.33 \mathrm{~b}$ \\
\hline \multicolumn{2}{|l|}{$100 \mathrm{ml}$} & $1.61 \mathrm{a}$ & $1.61 \mathrm{a}$ & $1.77 \mathrm{a}$ & $1.78 \mathrm{a}$ & $16.67 \mathrm{a}$ & $16.83 \mathrm{a}$ \\
\hline \multicolumn{8}{|c|}{ Effect of planting media * } \\
\hline \multicolumn{2}{|l|}{$\mathrm{T}_{1}$} & $1.62 \mathrm{a}$ & $1.61 \mathrm{a}$ & $1.65 \mathrm{~d}$ & $1.64 \mathrm{~cd}$ & $2.89 \mathrm{~d}$ & $3.00 \mathrm{~d}$ \\
\hline \multicolumn{2}{|l|}{$\mathrm{T}_{2}$} & $1.61 \mathrm{~b}$ & $1.61 \mathrm{a}$ & $1.73 \mathrm{c}$ & $1.72 \mathrm{c}$ & $12.00 \mathrm{c}$ & $11.67 \mathrm{c}$ \\
\hline \multicolumn{2}{|l|}{$\mathrm{T}_{3}$} & $1.60 \mathrm{~b}$ & $1.60 \mathrm{a}$ & $1.77 \mathrm{a}$ & $1.76 \mathrm{a}$ & $16.78 \mathrm{a}$ & $15.56 \mathrm{a}$ \\
\hline \multicolumn{2}{|l|}{$\mathrm{T}_{4}$} & $1.60 \mathrm{~b}$ & $1.60 \mathrm{a}$ & $1.75 \mathrm{~b}$ & $1.74 \mathrm{~b}$ & $14.33 \mathrm{~b}$ & $13.67 \mathrm{~b}$ \\
\hline \multicolumn{8}{|c|}{ Effect of interaction between EM application and planting media } \\
\hline \multirow{3}{*}{$\begin{array}{c}\text { EM } \\
\text { application }\end{array}$} & \multirow{3}{*}{ planting media * } & \multicolumn{6}{|c|}{ Leaves nitrogen content (\%) } \\
\hline & & \multicolumn{2}{|c|}{ at planting } & \multicolumn{2}{|c|}{ at 12 month } & \multicolumn{2}{|c|}{ Increasing rate } \\
\hline & & $\begin{array}{c}\text { Season } \\
2012 \\
\end{array}$ & $\begin{array}{c}\text { Season } \\
2013 \\
\end{array}$ & $\begin{array}{c}\text { Season } \\
2012 \\
\end{array}$ & $\begin{array}{c}\text { Season } \\
2013 \\
\end{array}$ & $\begin{array}{c}\text { Season } \\
2012 \\
\end{array}$ & $\begin{array}{c}\text { Season } \\
2013 \\
\end{array}$ \\
\hline \multirow{4}{*}{$0 \mathrm{ml}$} & $\mathrm{T}_{1}$ & $1.63 \mathrm{a}$ & $1.62 \mathrm{a}$ & $1.64 \mathrm{j}$ & $1.63 \mathrm{i}$ & $1.33 \mathrm{j}$ & $1.00 \mathrm{~h}$ \\
\hline & $\mathrm{T}_{2}$ & $1.61 \mathrm{a}-\mathrm{d}$ & $1.61 \mathrm{abc}$ & $1.68 \mathrm{gh}$ & $1.67 \mathrm{~g}$ & $6.67 \mathrm{~h}$ & $6.33 \mathrm{f}$ \\
\hline & $\mathrm{T}_{3}$ & $1.60 \mathrm{~d}$ & $1.60 \mathrm{bc}$ & $1.70 \mathrm{f}$ & $1.70 \mathrm{f}$ & $10.67 \mathrm{f}$ & $10.00 \mathrm{e}$ \\
\hline & $\mathrm{T}_{4}$ & $1.60 \mathrm{bcd}$ & $1.61 \mathrm{c}$ & $1.69 \mathrm{fg}$ & $1.69 \mathrm{fg}$ & $8.67 \mathrm{~g}$ & $9.67 \mathrm{e}$ \\
\hline \multirow{4}{*}{$50 \mathrm{ml}$} & $\mathrm{T}_{1}$ & $1.62 \mathrm{ab}$ & $1.60 \mathrm{ab}$ & $1.65 \mathrm{ij}$ & 1.64hi & $3.00 \mathrm{i}$ & $3.00 \mathrm{c}$ \\
\hline & $\mathrm{T}_{2}$ & $1.60 \mathrm{~cd}$ & $1.61 b c$ & $1.72 \mathrm{e}$ & $1.71 \mathrm{ef}$ & $12.33 \mathrm{e}$ & $10.67 \mathrm{de}$ \\
\hline & $\mathrm{T}_{3}$ & $1.61 \mathrm{bcd}$ & $1.60 \mathrm{ab}$ & $1.76 \mathrm{~d}$ & $1.74 \mathrm{~d}$ & $15.33 \mathrm{~d}$ & $12.33 \mathrm{~d}$ \\
\hline & $\mathrm{T}_{4}$ & $1.60 \mathrm{bcd}$ & $1.61 \mathrm{abc}$ & $1.74 \mathrm{de}$ & $1.72 \mathrm{de}$ & $13.67 \mathrm{de}$ & $11.33 \mathrm{de}$ \\
\hline \multirow{4}{*}{$100 \mathrm{ml}$} & $\mathrm{T}_{1}$ & $1.62 \mathrm{abc}$ & $1.60 \mathrm{abc}$ & $1.66 \mathrm{hi}$ & $1.65 \mathrm{~h}$ & $4.33 \mathrm{i}$ & $5.00 \mathrm{f}$ \\
\hline & $\mathrm{T}_{2}$ & $1.61 \mathrm{a}-\mathrm{d}$ & $1.61 \mathrm{abc}$ & $1.78 \mathrm{c}$ & $1.79 \mathrm{c}$ & $17.00 \mathrm{c}$ & $18.00 \mathrm{c}$ \\
\hline & $\mathrm{T}_{3}$ & $1.60 \mathrm{~cd}$ & $1.60 \mathrm{bc}$ & $1.85 \mathrm{a}$ & $1.84 \mathrm{a}$ & $24.67 \mathrm{a}$ & $24.33 \mathrm{a}$ \\
\hline & $\mathrm{T}_{4}$ & $1.60 \mathrm{~cd}$ & $1.61 \mathrm{abc}$ & $1.81 \mathrm{~b}$ & $1.81 \mathrm{~b}$ & $20.67 b$ & $20.00 \mathrm{~b}$ \\
\hline
\end{tabular}

\section{Leaf Iron, Zinc, Cupper and Manganese content \%}

Concerning the results in Table 9, 10, 11 and 12, data showed significantly increase in leaf iron, zinc, cupper and manganese content at 12 month of planting in both seasons. However, EM with high level raised significantly the rate of iron, zinc, cupper and manganese content in both seasons.

In addition, leaf iron, zinc, cupper and manganese content was affected significantly by different planting media used in both seasons. It was clearly noticed that $\mathrm{T}_{3}$ increased all of iron, zinc, cupper and manganese content and rate of iron ( 21.00 in the $1^{\text {st }}$ and $21.22 \%$ in the $2^{\text {nd }}$ seasons $)$, zinc $\left(24.33\right.$ in the $1^{\text {st }}$ and $24.78 \%$ in the $2^{\text {nd }}$ seasons $)$, cupper ( 15.44 in the $1^{\text {st }}$ and $15.56 \%$ in the $2^{\text {nd }}$ seasons $)$ and manganese $(26.56$ $\%$ in both seasons) comparing with other soil treatments used.

The interaction between EM applications and planting media showed that, $\mathrm{T}_{3}$ with high level of EM application was the best treatments that produced the highest iron, zinc, cupper and manganese content and rate of $\mathrm{Fe}, \mathrm{Zn}, \mathrm{Cu}$ and $\mathrm{Mn}$ increase in offshoots leaves comparing with other interactions used in both seasons.

Generally, these results are in agreement with (Abd-El-Messeih et al., 2005) who said that adding EM to the soil increased the vegetative growth, leaf area, leaf chlorophyll, leaf mineral values Fe, $\mathrm{Zn}$, and Mn as compared with the untreated Le Conte pear tree. In addition, El- Kosary, et al., (2008) who added that the planting media affected significantly on leaf mineral content of Zaghloul date palm cultivar in the nursery. Effective microorganisms (EM) with organic materials can be added to the soil, to stimulate the supply and release of nutrients Jakubus et al., (2012). 
Table 7: Effect of EM application and different planting media on leaf phosphorus content (\%) of Hayany date palm offshoots during 2012 and 2013 seasons.

\begin{tabular}{|c|c|c|c|c|c|c|c|}
\hline & & \multicolumn{6}{|c|}{ Leaves phosphorus content $(\%)$} \\
\hline \multirow{2}{*}{\multicolumn{2}{|c|}{ Treatments }} & \multicolumn{2}{|c|}{ at planting } & \multicolumn{2}{|c|}{ at 12 month } & \multicolumn{2}{|c|}{ Increasing rate } \\
\hline & & $\begin{array}{c}\text { Season } \\
2012 \\
\end{array}$ & $\begin{array}{c}\text { Season } \\
2013 \\
\end{array}$ & $\begin{array}{c}\text { Season } \\
2012 \\
\end{array}$ & $\begin{array}{c}\text { Season } \\
2013 \\
\end{array}$ & $\begin{array}{c}\text { Season } \\
2012 \\
\end{array}$ & $\begin{array}{c}\text { Season } \\
2013 \\
\end{array}$ \\
\hline \multicolumn{8}{|c|}{ Effect of EM application } \\
\hline \multicolumn{2}{|l|}{$0 \mathrm{ml}$} & $0.22 \mathrm{ab}$ & $0.22 \mathrm{a}$ & $0.30 \mathrm{c}$ & $0.29 \mathrm{c}$ & $7.75 \mathrm{c}$ & $7.33 \mathrm{c}$ \\
\hline \multicolumn{2}{|l|}{$50 \mathrm{ml}$} & $0.23 \mathrm{a}$ & $0.21 \mathrm{ab}$ & $0.33 b$ & $0.32 b$ & $9.83 b$ & $11.17 \mathrm{~b}$ \\
\hline \multicolumn{2}{|l|}{$100 \mathrm{ml}$} & $0.21 \mathrm{~b}$ & $0.21 \mathrm{a}$ & $0.35 \mathrm{a}$ & $0.35 \mathrm{a}$ & $13.75 \mathrm{a}$ & $14.42 \mathrm{a}$ \\
\hline \multicolumn{8}{|c|}{ Effect of planting media * } \\
\hline \multicolumn{2}{|l|}{$\mathrm{T}_{1}$} & $0.23 \mathrm{a}$ & $0.23 \mathrm{a}$ & $0.28 \mathrm{~d}$ & $0.28 \mathrm{~d}$ & $5.22 \mathrm{~d}$ & $5.22 \mathrm{~d}$ \\
\hline \multicolumn{2}{|l|}{$\mathrm{T}_{2}$} & $0.22 b$ & $0.21 b$ & $0.33 \mathrm{c}$ & $0.32 \mathrm{c}$ & $10.89 \mathrm{c}$ & $11.44 \mathrm{c}$ \\
\hline \multicolumn{2}{|l|}{$\mathrm{T}_{3}$} & $0.21 \mathrm{~b}$ & $0.20 \mathrm{~b}$ & $0.35 \mathrm{a}$ & $0.35 \mathrm{a}$ & $13.56 \mathrm{a}$ & $14.44 \mathrm{a}$ \\
\hline \multicolumn{2}{|l|}{$\mathrm{T}_{4}$} & $0.22 \mathrm{~b}$ & $0.21 \mathrm{~b}$ & $0.34 \mathrm{~b}$ & $0.34 \mathrm{~b}$ & $12.11 \mathrm{~b}$ & $12.78 \mathrm{~b}$ \\
\hline \multicolumn{8}{|c|}{ Effect of interaction between EM application and planting media } \\
\hline \multirow{3}{*}{$\begin{array}{c}\text { EM } \\
\text { application }\end{array}$} & \multirow{3}{*}{ planting media * } & \multicolumn{6}{|c|}{ Leaves phosphorus content (\%) } \\
\hline & & \multicolumn{2}{|c|}{ at planting } & \multicolumn{2}{|c|}{ at 12 month } & \multicolumn{2}{|c|}{ Increasing rate } \\
\hline & & $\begin{array}{c}\text { Season } \\
2012 \\
\end{array}$ & $\begin{array}{c}\text { Season } \\
2013 \\
\end{array}$ & $\begin{array}{c}\text { Season } \\
2012 \\
\end{array}$ & $\begin{array}{c}\text { Season } \\
2013 \\
\end{array}$ & $\begin{array}{c}\text { Season } \\
2012 \\
\end{array}$ & $\begin{array}{c}\text { Season } \\
2013 \\
\end{array}$ \\
\hline \multirow{4}{*}{$0 \mathrm{ml}$} & $\mathrm{T}_{1}$ & $0.24 \mathrm{a}$ & $0.23 \mathrm{a}$ & $0.27 \mathrm{i}$ & $0.27 \mathrm{j}$ & $3.33 \mathrm{i}$ & $3.67 \mathrm{j}$ \\
\hline & $\mathrm{T}_{2}$ & $0.21 \mathrm{~cd}$ & $0.22 \mathrm{abc}$ & $0.29 \mathrm{fgh}$ & $0.29 \mathrm{hi}$ & $8.33 \mathrm{~g}$ & $7.00 \mathrm{~h}$ \\
\hline & $\mathrm{T}_{3}$ & $0.21 \mathrm{~cd}$ & $0.21 \mathrm{bcd}$ & $0.31 \mathrm{ef}$ & $0.31 \mathrm{fg}$ & $10.00 \mathrm{ef}$ & $10.00 \mathrm{f}$ \\
\hline & $\mathrm{T}_{4}$ & $0.21 \mathrm{~cd}$ & $0.21 \mathrm{bcd}$ & $0.30 \mathrm{fg}$ & $0.30 \mathrm{gh}$ & $9.33 \mathrm{fg}$ & $8.67 \mathrm{~g}$ \\
\hline \multirow{4}{*}{$50 \mathrm{ml}$} & $\mathrm{T}_{1}$ & $0.22 b c$ & $0.22 \mathrm{ab}$ & $0.28 \mathrm{hi}$ & $0.28 \mathrm{ij}$ & $6.00 \mathrm{~h}$ & $5.67 \mathrm{i}$ \\
\hline & $\mathrm{T}_{2}$ & $0.22 \mathrm{abc}$ & $0.21 \mathrm{bcd}$ & $0.33 \mathrm{de}$ & $0.32 \mathrm{ef}$ & $10.33 \mathrm{ef}$ & $11.33 \mathrm{e}$ \\
\hline & $\mathrm{T}_{3}$ & $0.23 \mathrm{ab}$ & $0.20 \mathrm{~cd}$ & $0.35 \mathrm{c}$ & $0.35 \mathrm{~cd}$ & $12.00 \mathrm{~d}$ & $14.67 \mathrm{c}$ \\
\hline & $\mathrm{T}_{4}$ & $0.23 \mathrm{ab}$ & $0.21 \mathrm{bcd}$ & $0.34 \mathrm{~cd}$ & $0.34 \mathrm{de}$ & $11.00 \mathrm{de}$ & $13.00 \mathrm{~d}$ \\
\hline \multirow{4}{*}{$100 \mathrm{ml}$} & $\mathrm{T}_{1}$ & $0.23 \mathrm{abc}$ & $0.22 \mathrm{abc}$ & $0.29 \mathrm{ghi}$ & 0.28 hig & $6.33 \mathrm{~h}$ & $6.33 \mathrm{hi}$ \\
\hline & $\mathrm{T}_{2}$ & $0.22 b c$ & $0.20 \mathrm{~d}$ & $0.36 \mathrm{bc}$ & $0.36 \mathrm{bc}$ & $14.00 \mathrm{c}$ & $16.00 \mathrm{~b}$ \\
\hline & $\mathrm{T}_{3}$ & $0.20 \mathrm{~d}$ & $0.20 \mathrm{~d}$ & $0.39 \mathrm{a}$ & $0.39 \mathrm{a}$ & $18.67 \mathrm{a}$ & $18.67 \mathrm{a}$ \\
\hline & $\mathrm{T}_{4}$ & $0.21 \mathrm{~cd}$ & $0.21 \mathrm{bcd}$ & $0.37 \mathrm{ab}$ & $0.37 \mathrm{ab}$ & $16.00 \mathrm{~b}$ & $16.67 \mathrm{~b}$ \\
\hline
\end{tabular}

Table 8: Effect of EM application and different planting media on leaf potassium content (\%) of Hayany date palm offshoots during 2012 and 2013 seasons.

\begin{tabular}{|c|c|c|c|c|c|c|c|}
\hline \multirow{3}{*}{\multicolumn{2}{|c|}{ Treatments }} & \multicolumn{6}{|c|}{ Leaves potassium content $(\%)$} \\
\hline & & \multicolumn{2}{|c|}{ at planting } & \multicolumn{2}{|c|}{ at 12 month } & \multicolumn{2}{|c|}{ Increasing rate } \\
\hline & & $\begin{array}{c}\text { Season } \\
2012\end{array}$ & $\begin{array}{c}\text { Season } \\
2013\end{array}$ & $\begin{array}{c}\text { Season } \\
2012\end{array}$ & $\begin{array}{c}\text { Season } \\
2013\end{array}$ & $\begin{array}{c}\text { Season } \\
2012\end{array}$ & $\begin{array}{c}\text { Season } \\
2013\end{array}$ \\
\hline \multicolumn{8}{|c|}{ Effect of EM application } \\
\hline \multicolumn{2}{|c|}{$0 \mathrm{ml}$} & $0.74 \mathrm{a}$ & $0.73 a$ & $0.85 \mathrm{c}$ & $0.85 \mathrm{c}$ & $10.83 \mathrm{c}$ & $11.58 \mathrm{c}$ \\
\hline \multicolumn{2}{|l|}{$50 \mathrm{ml}$} & $0.73 \mathrm{ab}$ & $0.72 \mathrm{ab}$ & $0.88 \mathrm{~b}$ & $0.88 \mathrm{~b}$ & $15.42 \mathrm{~b}$ & $15.67 \mathrm{~b}$ \\
\hline \multicolumn{2}{|l|}{$100 \mathrm{ml}$} & $0.72 b$ & $0.71 \mathrm{~b}$ & $0.93 \mathrm{a}$ & $0.92 \mathrm{a}$ & $20.75 a$ & $20.58 \mathrm{a}$ \\
\hline \multicolumn{8}{|c|}{ Effect of planting media * } \\
\hline \multicolumn{2}{|c|}{$\mathrm{T}_{1}$} & $0.74 \mathrm{a}$ & $0.75 \mathrm{a}$ & $0.81 \mathrm{~d}$ & $0.81 \mathrm{c}$ & $7.00 \mathrm{~d}$ & $6.33 \mathrm{~d}$ \\
\hline \multicolumn{2}{|l|}{$\mathrm{T}_{2}$} & $0.73 b$ & $0.72 b$ & $0.90 \mathrm{c}$ & $0.90 \mathrm{~b}$ & $16.67 \mathrm{c}$ & $17.78 \mathrm{c}$ \\
\hline \multicolumn{2}{|l|}{$\mathrm{T}_{3}$} & $0.72 b$ & $0.71 \mathrm{~b}$ & $0.93 \mathrm{a}$ & $0.92 \mathrm{a}$ & $20.33 a$ & $20.67 \mathrm{a}$ \\
\hline \multicolumn{2}{|l|}{$\mathrm{T}_{4}$} & $0.72 b$ & $0.71 \mathrm{~b}$ & $0.91 \mathrm{~b}$ & $0.90 \mathrm{~b}$ & $18.67 \mathrm{~b}$ & $19.00 \mathrm{~b}$ \\
\hline \multicolumn{8}{|c|}{ Effect of interaction between EM application and planting media } \\
\hline \multirow{3}{*}{$\begin{array}{c}\text { EM } \\
\text { application }\end{array}$} & \multirow{3}{*}{ planting media * } & \multicolumn{6}{|c|}{ Leaves potassium content (\%) } \\
\hline & & \multicolumn{2}{|c|}{ at planting } & \multicolumn{2}{|c|}{ at 12 month } & \multicolumn{2}{|c|}{ Increasing rate } \\
\hline & & $\begin{array}{c}\text { Season } \\
2012 \\
\end{array}$ & $\begin{array}{c}\text { Season } \\
2013 \\
\end{array}$ & $\begin{array}{c}\text { Season } \\
2012 \\
\end{array}$ & $\begin{array}{c}\text { Season } \\
2013 \\
\end{array}$ & $\begin{array}{c}\text { Season } \\
2012 \\
\end{array}$ & $\begin{array}{c}\text { Season } \\
2013 \\
\end{array}$ \\
\hline \multirow{5}{*}{$0 \mathrm{ml}$} & $\mathrm{T}_{1}$ & $0.75 \mathrm{a}$ & $0.75 \mathrm{a}$ & $0.80 \mathrm{i}$ & $0.80 \mathrm{~h}$ & $5.00 \mathrm{j}$ & $4.33 \mathrm{i}$ \\
\hline & $\mathrm{T}_{2}$ & $0.74 \mathrm{a}-\mathrm{d}$ & $0.72 \mathrm{~cd}$ & $0.85 \mathrm{~g}$ & $0.85 \mathrm{f}$ & $11.33 \mathrm{~h}$ & $12.67 \mathrm{f}$ \\
\hline & $\mathrm{T}_{3}$ & $0.73 \mathrm{a}-\mathrm{d}$ & $0.72 \mathrm{~cd}$ & $0.87 \mathrm{ef}$ & $0.87 \mathrm{e}$ & $14.00 \mathrm{~g}$ & $15.00 \mathrm{e}$ \\
\hline & $\mathrm{T}_{4}$ & $0.73 \mathrm{bcd}$ & $0.72 \mathrm{~cd}$ & $0.86 f g$ & $0.86 \mathrm{ef}$ & $13.00 \mathrm{~g}$ & $14.33 \mathrm{e}$ \\
\hline & $\mathrm{T}_{1}$ & $0.74 \mathrm{ab}$ & $0.75 \mathrm{ab}$ & $0.82 \mathrm{hi}$ & $0.81 \mathrm{gh}$ & $7.00 \mathrm{i}$ & $6.00 \mathrm{~h}$ \\
\hline
\end{tabular}


Effect of Some Agro-Management Systems on Growth and Production of Date Palm Off-Shoots under

\begin{tabular}{|l|l|l|l|l|l|l|l|}
\hline $50 \mathrm{ml}$ & $\mathrm{T}_{2}$ & $0.73 \mathrm{bcd}$ & $0.72 \mathrm{~cd}$ & $0.89 \mathrm{de}$ & $0.89 \mathrm{~d}$ & $16.00 \mathrm{f}$ & $17.33 \mathrm{~d}$ \\
\cline { 2 - 8 } & $\mathrm{T}_{3}$ & $0.73 \mathrm{~b}-\mathrm{e}$ & $0.71 \mathrm{~d}$ & $0.93 \mathrm{c}$ & $0.92 \mathrm{c}$ & $20.33 \mathrm{~d}$ & $21.00 \mathrm{c}$ \\
\cline { 2 - 8 } & $\mathrm{T}_{4}$ & $0.72 \mathrm{de}$ & $0.72 \mathrm{~cd}$ & $0.90 \mathrm{~d}$ & $0.90 \mathrm{~d}$ & $18.00 \mathrm{e}$ & $18.33 \mathrm{~d}$ \\
\hline \multirow{5}{*}{$100 \mathrm{ml}$} & $\mathrm{T}_{1}$ & $0.74 \mathrm{abc}$ & $0.73 \mathrm{bc}$ & $0.83 \mathrm{~h}$ & $0.82 \mathrm{~g}$ & $8.67 \mathrm{i}$ & $8.67 \mathrm{~g}$ \\
\cline { 2 - 8 } & $\mathrm{T}_{2}$ & $0.72 \mathrm{cde}$ & $0.72 \mathrm{~cd}$ & $0.95 \mathrm{~b}$ & $0.95 \mathrm{ab}$ & $22.67 \mathrm{c}$ & $23.33 \mathrm{~b}$ \\
\cline { 2 - 8 } & $\mathrm{T}_{3}$ & $0.71 \mathrm{e}$ & $0.71 \mathrm{~d}$ & $0.98 \mathrm{a}$ & $0.97 \mathrm{a}$ & $26.67 \mathrm{a}$ & $26.00 \mathrm{a}$ \\
\cline { 2 - 8 } & $\mathrm{T}_{4}$ & $0.72 \mathrm{de}$ & $0.71 \mathrm{~d}$ & $0.97 \mathrm{a}$ & $0.95 \mathrm{~b}$ & $25.00 \mathrm{~b}$ & $24.33 \mathrm{~b}$ \\
\hline
\end{tabular}

${ }^{*} \mathrm{~T}_{1}$ : Control (normal sandy soil), $\mathrm{T}_{2}$ c cattle manure + sandy soil (1:2,v:v), $\mathrm{T}_{3}$ : goat manure + sandy soil $(1: 2, \mathrm{v}: \mathrm{v})$ and $\mathrm{T}_{4}$ : compost + sandy soil $(1: 2, \mathrm{v}: \mathrm{v})$.

Means having the same letter (s) in each column, row or interaction are not significantly different at $5 \%$ level.

Table 9: Effect of EM application and different planting media on leaf iron content (\%) of Hayany date palm offshoots during 2012 and 2013 seasons.

\begin{tabular}{|c|c|c|c|c|c|c|c|}
\hline \multirow{3}{*}{\multicolumn{2}{|c|}{ Treatments }} & \multicolumn{6}{|c|}{ Leaves iron content ( $\%)$} \\
\hline & & \multicolumn{2}{|c|}{ at planting } & \multicolumn{2}{|c|}{ at 12 month } & \multicolumn{2}{|c|}{ Increasing rate } \\
\hline & & $\begin{array}{l}\text { Season } \\
2012\end{array}$ & $\begin{array}{l}\text { Season } \\
2013 \\
\end{array}$ & $\begin{array}{l}\text { Season } \\
2012 \\
\end{array}$ & $\begin{array}{l}\text { Season } \\
2013 \\
\end{array}$ & $\begin{array}{l}\text { Season } \\
2012\end{array}$ & $\begin{array}{l}\text { Season } \\
2013 \\
\end{array}$ \\
\hline \multicolumn{8}{|c|}{ Effect of EM application } \\
\hline \multicolumn{2}{|l|}{$0 \mathrm{ml}$} & $152.92 \mathrm{a}$ & $152.33 \mathrm{a}$ & $162.00 \mathrm{c}$ & $162.16 \mathrm{c}$ & $9.08 \mathrm{c}$ & $9.83 \mathrm{c}$ \\
\hline \multicolumn{2}{|l|}{$50 \mathrm{ml}$} & $152.25 \mathrm{~b}$ & $151.58 \mathrm{a}$ & $166.67 \mathrm{~b}$ & $165.92 \mathrm{~b}$ & $14.42 \mathrm{~b}$ & $13.58 \mathrm{~b}$ \\
\hline \multicolumn{2}{|l|}{$100 \mathrm{ml}$} & $151.75 b$ & $151.92 \mathrm{a}$ & $173.17 \mathrm{a}$ & $173.00 \mathrm{a}$ & $21.42 \mathrm{a}$ & $21.08 \mathrm{a}$ \\
\hline \multicolumn{8}{|c|}{ Effect of planting media * } \\
\hline \multicolumn{2}{|l|}{$\mathrm{T}_{1}$} & $153.89 \mathrm{a}$ & $152.89 \mathrm{a}$ & $159.89 d$ & $159.00 \mathrm{~d}$ & $6.00 \mathrm{~d}$ & $5.11 \mathrm{~d}$ \\
\hline \multicolumn{2}{|l|}{$\mathrm{T}_{2}$} & $152.22 \mathrm{~b}$ & $152.11 \mathrm{ab}$ & $167.11 \mathrm{c}$ & $166.56 \mathrm{c}$ & $14.89 \mathrm{c}$ & $14.44 \mathrm{c}$ \\
\hline \multicolumn{2}{|l|}{$\mathrm{T}_{3}$} & $151.56 \mathrm{c}$ & $151.33 b$ & $172.56 \mathrm{a}$ & $172.56 \mathrm{a}$ & $21.00 \mathrm{a}$ & $21.22 \mathrm{a}$ \\
\hline \multicolumn{2}{|l|}{$\mathrm{T}_{4}$} & $151.56 \mathrm{c}$ & $151.44 \mathrm{~b}$ & $169.56 \mathrm{~b}$ & $170.00 \mathrm{~b}$ & $18.00 \mathrm{~b}$ & $18.56 \mathrm{~b}$ \\
\hline \multicolumn{8}{|c|}{ Effect of interaction between EM application and planting media } \\
\hline \multirow{3}{*}{$\begin{array}{c}\text { EM } \\
\text { application }\end{array}$} & \multirow{3}{*}{ planting media * } & \multicolumn{6}{|c|}{ Leaves iron content $(\%)$} \\
\hline & & \multicolumn{2}{|c|}{ at planting } & \multicolumn{2}{|c|}{ at 12 month } & \multicolumn{2}{|c|}{ Increasing rate } \\
\hline & & $\begin{array}{c}\text { Season } \\
2012 \\
\end{array}$ & $\begin{array}{c}\text { Season } \\
2013 \\
\end{array}$ & $\begin{array}{c}\text { Season } \\
2012 \\
\end{array}$ & $\begin{array}{c}\text { Season } \\
2013 \\
\end{array}$ & $\begin{array}{c}\text { Season } \\
2012 \\
\end{array}$ & $\begin{array}{c}\text { Season } \\
2013 \\
\end{array}$ \\
\hline \multirow{4}{*}{$0 \mathrm{ml}$} & $\mathbf{T}_{1}$ & $154.67 \mathrm{a}$ & $154.33 \mathrm{a}$ & $159.00 \mathrm{i}$ & $158.33 \mathrm{~g}$ & $4.33 \mathrm{j}$ & $4.00 \mathrm{~h}$ \\
\hline & $\mathbf{T}_{2}$ & $153.00 \mathrm{bc}$ & $152.67 \mathrm{abc}$ & $161.33 \mathrm{gh}$ & $162.00 \mathrm{f}$ & $8.33 \mathrm{~h}$ & $9.33 \mathrm{~g}$ \\
\hline & $\mathbf{T}_{3}$ & $152.00 \mathrm{~cd}$ & $151.33 \mathrm{c}$ & $165.00 \mathrm{f}$ & $165.00 \mathrm{e}$ & $13.00 \mathrm{f}$ & $13.67 \mathrm{ef}$ \\
\hline & $\mathbf{T}_{4}$ & $152.00 \mathrm{~cd}$ & $151.00 \mathrm{c}$ & $162.67 \mathrm{~g}$ & $163.33 \mathrm{ef}$ & $10.67 \mathrm{~g}$ & $12.33 \mathrm{f}$ \\
\hline \multirow{4}{*}{$50 \mathrm{ml}$} & $\mathbf{T}_{1}$ & $154.00 \mathrm{ab}$ & $150.33 \mathrm{c}$ & 160.00hi & $158.67 \mathrm{~g}$ & $6.00 \mathrm{ij}$ & $5.33 \mathrm{~h}$ \\
\hline & $\mathbf{T}_{2}$ & $152.00 \mathrm{~cd}$ & $152.33 \mathrm{abc}$ & $167.33 \mathrm{e}$ & $167.00 \mathrm{~d}$ & $15.33 \mathrm{e}$ & $14.67 \mathrm{de}$ \\
\hline & $\mathbf{T}_{3}$ & $151.67 \mathrm{~d}$ & $151.67 \mathrm{bc}$ & $170.67 \mathrm{~d}$ & $170.00 \mathrm{c}$ & $19.00 \mathrm{~d}$ & $18.33 \mathrm{c}$ \\
\hline & $\mathbf{T}_{4}$ & $151.33 \mathrm{~d}$ & $152.00 \mathrm{abc}$ & $168.67 \mathrm{e}$ & $168.00 \mathrm{~d}$ & $17.33 \mathrm{~d}$ & $16.00 \mathrm{~d}$ \\
\hline \multirow{4}{*}{$100 \mathrm{ml}$} & $\mathbf{T}_{1}$ & $153.00 \mathrm{bc}$ & $154.00 \mathrm{ab}$ & $160.67 \mathrm{~h}$ & $160.00 \mathrm{~g}$ & 7.67hi & $6.00 \mathrm{~h}$ \\
\hline & $\mathbf{T}_{2}$ & $151.67 \mathrm{~d}$ & $151.33 \mathrm{c}$ & $172.67 \mathrm{c}$ & $170.67 \mathrm{c}$ & $21.00 \mathrm{c}$ & $19.33 c$ \\
\hline & $\mathbf{T}_{3}$ & $151.00 \mathrm{~d}$ & $151.00 \mathrm{c}$ & $182.00 \mathrm{a}$ & $182.67 \mathrm{a}$ & $31.00 \mathrm{a}$ & $31.67 \mathrm{a}$ \\
\hline & $T_{4}$ & $151.33 \mathrm{~d}$ & $151.33 \mathrm{c}$ & $177.33 b$ & $178.67 \mathrm{~b}$ & $26.00 \mathrm{~b}$ & $27.33 b$ \\
\hline
\end{tabular}

Table 10: Effect of EM application and different planting media on leaf zinc content (\%) of Hayany date palm offshoots during 2012 and 2013 seasons.

\begin{tabular}{|c|c|c|c|c|c|c|c|}
\hline \multirow{3}{*}{\multicolumn{2}{|c|}{ Treatments }} & \multicolumn{6}{|c|}{ Leaves zinc content $(\%)$} \\
\hline & & \multicolumn{2}{|c|}{ at planting } & \multicolumn{2}{|c|}{ at 12 month } & \multicolumn{2}{|c|}{ Increasing rate } \\
\hline & & $\begin{array}{c}\text { Season } \\
2012\end{array}$ & $\begin{array}{c}\text { Season } \\
2013\end{array}$ & $\begin{array}{c}\text { Season } \\
2012\end{array}$ & $\begin{array}{c}\text { Season } \\
2013\end{array}$ & $\begin{array}{c}\text { Season } \\
2012\end{array}$ & $\begin{array}{c}\text { Season } \\
2013\end{array}$ \\
\hline \multicolumn{8}{|c|}{ Effect of EM application } \\
\hline $0 \mathrm{ml}$ & & $51.08 \mathrm{a}$ & $51.33 \mathrm{a}$ & $65.92 \mathrm{c}$ & $65.83 \mathrm{c}$ & $14.83 \mathrm{c}$ & $14.50 \mathrm{c}$ \\
\hline $50 \mathrm{ml}$ & & $50.33 b$ & $51.17 \mathrm{a}$ & $70.00 \mathrm{~b}$ & $70.25 b$ & $19.67 \mathrm{~b}$ & $19.58 \mathrm{~b}$ \\
\hline $100 \mathrm{ml}$ & & $50.75 \mathrm{ab}$ & $50.75 a$ & $74.33 \mathrm{a}$ & $74.67 \mathrm{a}$ & $23.58 \mathrm{a}$ & $23.92 \mathrm{a}$ \\
\hline \multicolumn{8}{|c|}{ Effect of planting media * } \\
\hline $\mathrm{T}_{1}$ & & $51.67 \mathrm{a}$ & $52.22 \mathrm{a}$ & $61.22 \mathrm{~d}$ & $61.44 d$ & $9.56 \mathrm{~d}$ & $9.22 \mathrm{~d}$ \\
\hline $\mathrm{T}_{2}$ & & $50.78 \mathrm{~b}$ & $50.78 \mathrm{~b}$ & $71.33 \mathrm{c}$ & $71.33 \mathrm{c}$ & $20.56 \mathrm{c}$ & $20.56 \mathrm{c}$ \\
\hline $\mathrm{T}_{3}$ & & $50.33 \mathrm{bc}$ & $50.33 b$ & $74.67 \mathrm{a}$ & $75.11 \mathrm{a}$ & $24.33 a$ & $24.78 \mathrm{a}$ \\
\hline $\mathrm{T}_{4}$ & & $50.11 \mathrm{c}$ & $51.00 \mathrm{~b}$ & $73.11 \mathrm{~b}$ & $73.11 \mathrm{~b}$ & $23.00 \mathrm{~b}$ & $22.78 b$ \\
\hline \multicolumn{8}{|c|}{ Effect of interaction between EM application and planting media } \\
\hline EM & planting media* & \multicolumn{6}{|c|}{ Leaves zinc content $(\%)$} \\
\hline
\end{tabular}


Effect of Some Agro-Management Systems on Growth and Production of Date Palm Off-Shoots under

\begin{tabular}{|c|l|c|c|c|c|c|c|}
\hline \multirow{5}{*}{ application } & & \multicolumn{2}{|c|}{ at planting } & \multicolumn{2}{c|}{ at 12 month } & \multicolumn{2}{c|}{ Increasing rate } \\
\cline { 2 - 7 } & & $\begin{array}{c}\text { Season } \\
\mathbf{2 0 1 2}\end{array}$ & $\begin{array}{c}\text { Season } \\
\mathbf{2 0 1 3}\end{array}$ & $\begin{array}{c}\text { Season } \\
\mathbf{2 0 1 2}\end{array}$ & $\begin{array}{c}\text { Season } \\
\mathbf{2 0 1 3}\end{array}$ & $\begin{array}{c}\text { Season } \\
\mathbf{2 0 1 2}\end{array}$ & $\begin{array}{c}\text { Season } \\
\mathbf{2 0 1 3}\end{array}$ \\
\hline \multirow{5}{*}{$0 \mathrm{ml}$} & $\mathrm{T}_{1}$ & $52.00 \mathrm{a}$ & $52.33 \mathrm{a}$ & $60.00 \mathrm{j}$ & 60.331 & $8.00 \mathrm{i}$ & $8.00 \mathrm{k}$ \\
\cline { 2 - 7 } & $\mathrm{T}_{2}$ & $51.33 \mathrm{ab}$ & $51.33 \mathrm{abc}$ & $65.33 \mathrm{~h}$ & $65.00 \mathrm{i}$ & $14.00 \mathrm{~g}$ & $13.67 \mathrm{i}$ \\
\cline { 2 - 7 } & $\mathrm{T}_{3}$ & $51.00 \mathrm{abc}$ & $51.00 \mathrm{bcd}$ & $70.00 \mathrm{f}$ & $70.00 \mathrm{~g}$ & $19.00 \mathrm{f}$ & $19.00 \mathrm{~g}$ \\
\cline { 2 - 7 } & $\mathrm{T}_{4}$ & $50.00 \mathrm{c}$ & $50.67 \mathrm{~cd}$ & $68.33 \mathrm{~g}$ & $68.00 \mathrm{~h}$ & $18.33 \mathrm{f}$ & $17.33 \mathrm{~h}$ \\
\hline \multirow{5}{*}{$50 \mathrm{ml}$} & $\mathrm{T}_{1}$ & $51.00 \mathrm{abc}$ & $52.33 \mathrm{a}$ & $60.67 \mathrm{j}$ & $61.00 \mathrm{k}$ & $9.67 \mathrm{hf}$ & $8.67 \mathrm{k}$ \\
\cline { 2 - 7 } & $\mathrm{T}_{2}$ & $50.33 \mathrm{c}$ & $50.33 \mathrm{~cd}$ & $72.33 \mathrm{e}$ & $72.00 \mathrm{f}$ & $22.00 \mathrm{hi}$ & $21.67 \mathrm{f}$ \\
\cline { 2 - 7 } & $\mathrm{T}_{3}$ & $50.00 \mathrm{abc}$ & $50.00 \mathrm{~d}$ & $74.00 \mathrm{~d}$ & $75.00 \mathrm{~d}$ & $24.00 \mathrm{e}$ & $25.00 \mathrm{~d}$ \\
\cline { 2 - 7 } & $\mathrm{T}_{4}$ & $50.00 \mathrm{bc}$ & $52.00 \mathrm{ab}$ & $73.00 \mathrm{de}$ & $73.00 \mathrm{e}$ & $23.00 \mathrm{e}$ & $23.00 \mathrm{e}$ \\
\hline \multirow{5}{*}{$100 \mathrm{ml}$} & $\mathrm{T}_{1}$ & $52.00 \mathrm{bc}$ & $52.00 \mathrm{ab}$ & $63.00 \mathrm{i}$ & $63.00 \mathrm{j}$ & $11.00 \mathrm{~cd}$ & $11.00 \mathrm{j}$ \\
\cline { 2 - 7 } & $\mathrm{T}_{2}$ & $50.67 \mathrm{c}$ & $50.67 \mathrm{~cd}$ & $76.33 \mathrm{c}$ & $77.00 \mathrm{c}$ & $25.67 \mathrm{de}$ & $26.33 \mathrm{c}$ \\
\cline { 2 - 7 } & $\mathrm{T}_{3}$ & $50.00 \mathrm{a}$ & $50.00 \mathrm{~d}$ & $80.00 \mathrm{a}$ & $80.33 \mathrm{a}$ & $30.00 \mathrm{de}$ & $30.33 \mathrm{a}$ \\
\cline { 2 - 7 } & $\mathrm{T}_{4}$ & $50.33 \mathrm{~cd}$ & $78.00 \mathrm{~b}$ & $78.33 \mathrm{~b}$ & $27.67 \mathrm{~h}$ & $28.00 \mathrm{~b}$ \\
\hline
\end{tabular}

Table 11: Effect of EM application and different planting media on leaf cupper content (\%) of Hayany date palm offshoots during 2012 and 2013 seasons.

\begin{tabular}{|c|c|c|c|c|c|c|c|}
\hline & & \multicolumn{6}{|c|}{ Leaves cupper content $(\%)$} \\
\hline \multirow{2}{*}{\multicolumn{2}{|c|}{ Treatments }} & \multicolumn{2}{|c|}{ at planting } & \multicolumn{2}{|c|}{ at 12 month } & \multicolumn{2}{|c|}{ Increasing rate } \\
\hline & & $\begin{array}{c}\text { Season } \\
2012\end{array}$ & $\begin{array}{c}\text { Season } \\
2013\end{array}$ & $\begin{array}{c}\text { Season } \\
2012\end{array}$ & $\begin{array}{c}\text { Season } \\
2013 \\
\end{array}$ & $\begin{array}{c}\text { Season } \\
2012 \\
\end{array}$ & $\begin{array}{c}\text { Season } \\
2013 \\
\end{array}$ \\
\hline \multicolumn{8}{|c|}{ Effect of EM application } \\
\hline \multicolumn{2}{|l|}{$0 \mathrm{ml}$} & $27.75 \mathrm{a}$ & $27.92 a$ & $35.25 \mathrm{c}$ & $34.67 \mathrm{c}$ & $7.50 \mathrm{c}$ & $6.75 c$ \\
\hline \multicolumn{2}{|l|}{$50 \mathrm{ml}$} & $27.67 \mathrm{a}$ & $27.17 b$ & $38.17 \mathrm{~b}$ & $37.75 b$ & $10.50 \mathrm{~b}$ & $10.58 b$ \\
\hline \multicolumn{2}{|l|}{$100 \mathrm{ml}$} & $27.25 \mathrm{a}$ & $27.17 \mathrm{~b}$ & $44.17 \mathrm{a}$ & $43.58 \mathrm{a}$ & $16.92 \mathrm{a}$ & $16.42 \mathrm{a}$ \\
\hline \multicolumn{8}{|c|}{ Effect of planting media * } \\
\hline \multicolumn{2}{|c|}{$\mathrm{T}_{1}$} & $28.33 \mathrm{a}$ & $28.44 \mathrm{a}$ & $33.33 \mathrm{~d}$ & $31.89 \mathrm{~d}$ & $5.00 \mathrm{~d}$ & $3.44 \mathrm{~d}$ \\
\hline \multicolumn{2}{|l|}{$\mathrm{T}_{2}$} & $27.56 \mathrm{~b}$ & $27.22 b$ & $39.78 \mathrm{c}$ & $39.33 c$ & $12.22 \mathrm{c}$ & $12.11 \mathrm{c}$ \\
\hline \multicolumn{2}{|l|}{$\mathrm{T}_{3}$} & $27.11 \mathrm{~b}$ & $26.78 \mathrm{c}$ & $42.56 \mathrm{a}$ & $42.33 \mathrm{a}$ & $15.44 \mathrm{a}$ & $15.56 \mathrm{a}$ \\
\hline \multicolumn{2}{|l|}{$\mathrm{T}_{4}$} & $27.22 b$ & $27.22 b$ & $41.11 \mathrm{~b}$ & $41.11 \mathrm{~b}$ & $13.89 \mathrm{~b}$ & $13.89 \mathrm{~b}$ \\
\hline \multicolumn{8}{|c|}{ Effect of interaction between EM application and planting media } \\
\hline \multirow{3}{*}{$\begin{array}{c}\mathbf{E M} \\
\text { application }\end{array}$} & \multirow{3}{*}{ planting media * } & \multicolumn{6}{|c|}{ Leaves cupper content $(\%)$} \\
\hline & & \multicolumn{2}{|c|}{ at planting } & \multicolumn{2}{|c|}{ at 12 month } & \multicolumn{2}{|c|}{ Increasing rate } \\
\hline & & $\begin{array}{c}\text { Season } \\
2012\end{array}$ & $\begin{array}{c}\text { Season } \\
2013\end{array}$ & $\begin{array}{c}\text { Season } \\
2012\end{array}$ & $\begin{array}{c}\text { Season } \\
2013\end{array}$ & $\begin{array}{c}\text { Season } \\
2012\end{array}$ & $\begin{array}{c}\text { Season } \\
2013\end{array}$ \\
\hline \multirow{4}{*}{$0 \mathrm{ml}$} & $\mathrm{T}_{1}$ & $28.67 \mathrm{a}$ & $29.00 \mathrm{a}$ & $33.00 \mathrm{~h}$ & $31.33 \mathrm{j}$ & $4.33 \mathrm{~h}$ & $2.33 \mathrm{j}$ \\
\hline & $\mathrm{T}_{2}$ & $27.33 \mathrm{~cd}$ & $27.67 \mathrm{c}$ & $35.67 \mathrm{~g}$ & $35.00 \mathrm{~h}$ & $8.33 \mathrm{f}$ & $7.33 \mathrm{~h}$ \\
\hline & $\mathrm{T}_{3}$ & $27.33 \mathrm{~cd}$ & $27.00 \mathrm{~d}$ & $36.33 \mathrm{~g}$ & $36.00 \mathrm{~g}$ & $9.00 \mathrm{ef}$ & $9.00 \mathrm{~g}$ \\
\hline & $\mathrm{T}_{4}$ & $27.67 \mathrm{bcd}$ & $28.00 \mathrm{bc}$ & $36.00 \mathrm{~g}$ & $36.33 \mathrm{~g}$ & $8.33 \mathrm{f}$ & $8.33 \mathrm{~g}$ \\
\hline \multirow{4}{*}{$50 \mathrm{ml}$} & $\mathrm{T}_{1}$ & $28.33 \mathrm{ab}$ & $28.33 b$ & $33.33 \mathrm{~h}$ & $32.00 \mathrm{i}$ & $5.00 \mathrm{gh}$ & $3.67 \mathrm{i}$ \\
\hline & $\mathrm{T}_{2}$ & $28.33 \mathrm{ab}$ & $27.00 \mathrm{~d}$ & $38.33 \mathrm{f}$ & $38.00 \mathrm{f}$ & $10.00 \mathrm{e}$ & $11.00 \mathrm{f}$ \\
\hline & $\mathrm{T}_{3}$ & $27.00 \mathrm{~d}$ & $26.67 d$ & $41.00 \mathrm{~d}$ & $41.00 \mathrm{~d}$ & $14.00 \mathrm{~d}$ & $14.33 \mathrm{~d}$ \\
\hline & $\mathrm{T}_{4}$ & $27.00 \mathrm{~d}$ & $26.67 d$ & $40.00 \mathrm{e}$ & $40.00 \mathrm{e}$ & $13.00 \mathrm{~d}$ & $13.33 \mathrm{e}$ \\
\hline \multirow{4}{*}{$100 \mathrm{ml}$} & $\mathrm{T}_{1}$ & $28.00 \mathrm{abc}$ & $28.00 \mathrm{bc}$ & $33.67 \mathrm{~h}$ & $33.33 \mathrm{i}$ & $5.67 \mathrm{~g}$ & $4.33 \mathrm{i}$ \\
\hline & $\mathrm{T}_{2}$ & $27.00 \mathrm{~d}$ & $27.00 \mathrm{~d}$ & $45.33 c$ & $45.00 \mathrm{c}$ & $18.33 c$ & $18.00 \mathrm{c}$ \\
\hline & $\mathrm{T}_{3}$ & $27.00 \mathrm{~d}$ & $26.67 d$ & $50.33 a$ & $50.00 \mathrm{a}$ & $23.33 \mathrm{a}$ & $23.33 \mathrm{a}$ \\
\hline & $\mathrm{T}_{4}$ & $27.00 \mathrm{~d}$ & $27.00 \mathrm{~d}$ & $47.33 b$ & $47.00 \mathrm{~b}$ & $20.33 b$ & $20.00 \mathrm{~b}$ \\
\hline
\end{tabular}

Means having the same letter (s) in each Colum, row or interaction are not significantly different at $5 \%$ level. 
Table 12: Effect of EM application and different planting media on leaf manganese content (\%) of Hayany date palm offshoots during 2012 and 2013 season.

\begin{tabular}{|c|c|c|c|c|c|c|c|}
\hline \multirow{3}{*}{\multicolumn{2}{|c|}{ Treatments }} & \multicolumn{6}{|c|}{ Leaves manganese content (\%) } \\
\hline & & \multicolumn{2}{|c|}{ at planting } & \multicolumn{2}{|c|}{ at 12 month } & \multicolumn{2}{|c|}{ Increasing rate } \\
\hline & & $\begin{array}{c}\text { Season } \\
2012\end{array}$ & $\begin{array}{c}\text { Season } \\
2013\end{array}$ & $\begin{array}{c}\text { Season } \\
2012\end{array}$ & $\begin{array}{c}\text { Season } \\
2013\end{array}$ & $\begin{array}{c}\text { Season } \\
2012\end{array}$ & $\begin{array}{c}\text { Season } \\
2013\end{array}$ \\
\hline \multicolumn{8}{|c|}{ Effect of EM application } \\
\hline \multicolumn{2}{|l|}{$0 \mathrm{ml}$} & $53.08 \mathrm{a}$ & $53.25 \mathrm{a}$ & $65.92 \mathrm{c}$ & $65.33 \mathrm{c}$ & $12.83 \mathrm{c}$ & $12.08 \mathrm{c}$ \\
\hline \multicolumn{2}{|l|}{$50 \mathrm{ml}$} & $52.25 \mathrm{ab}$ & $51.42 b$ & $72.67 \mathrm{~b}$ & $72.08 \mathrm{~b}$ & $20.42 b$ & $20.67 b$ \\
\hline \multicolumn{2}{|l|}{$100 \mathrm{ml}$} & $51.33 \mathrm{a}$ & $51.25 \mathrm{~b}$ & $78.00 \mathrm{a}$ & $77.58 \mathrm{a}$ & $26.67 \mathrm{a}$ & $26.33 a$ \\
\hline \multicolumn{8}{|c|}{ Effect of planting media * } \\
\hline \multicolumn{2}{|l|}{$\mathrm{T}_{1}$} & $53.44 \mathrm{a}$ & $53.33 \mathrm{a}$ & $61.33 \mathrm{~d}$ & $61.00 \mathrm{~d}$ & $7.89 \mathrm{~d}$ & $7.67 \mathrm{~d}$ \\
\hline \multicolumn{2}{|l|}{$\mathrm{T}_{2}$} & $52.25 \mathrm{~b}$ & $51.89 \mathrm{~b}$ & $73.89 \mathrm{c}$ & $73.11 \mathrm{c}$ & $21.67 \mathrm{c}$ & $21.22 \mathrm{c}$ \\
\hline \multicolumn{2}{|l|}{$\mathrm{T}_{3}$} & $51.56 \mathrm{c}$ & $51.11 \mathrm{c}$ & $78.11 \mathrm{a}$ & $77.67 \mathrm{a}$ & $26.56 \mathrm{a}$ & $26.56 \mathrm{a}$ \\
\hline \multicolumn{2}{|l|}{$\mathrm{T}_{4}$} & $51.67 \mathrm{c}$ & $51.56 \mathrm{bc}$ & $75.44 \mathrm{~b}$ & $74.89 \mathrm{~b}$ & $23.78 \mathrm{~b}$ & $23.33 b$ \\
\hline \multicolumn{8}{|c|}{ Effect of interaction between EM application and planting media } \\
\hline \multirow{3}{*}{$\begin{array}{c}\text { EM } \\
\text { application }\end{array}$} & \multirow{3}{*}{ planting media * } & \multicolumn{6}{|c|}{ Leaves manganese content ( $\%)$} \\
\hline & & \multicolumn{2}{|c|}{ at planting } & \multicolumn{2}{|c|}{ at 12 month } & \multicolumn{2}{|c|}{ Increasing rate } \\
\hline & & $\begin{array}{c}\text { Season } \\
2012 \\
\end{array}$ & $\begin{array}{c}\text { Season } \\
2013 \\
\end{array}$ & $\begin{array}{c}\text { Season } \\
2012 \\
\end{array}$ & $\begin{array}{c}\text { Season } \\
2013 \\
\end{array}$ & $\begin{array}{c}\begin{array}{c}\text { Season } \\
2012\end{array} \\
\end{array}$ & $\begin{array}{c}\begin{array}{c}\text { Season } \\
2013\end{array} \\
\end{array}$ \\
\hline \multirow{4}{*}{$0 \mathrm{ml}$} & $\mathrm{T}_{1}$ & $54.00 \mathrm{a}$ & $54.00 \mathrm{a}$ & 60.001 & $60.00 \mathrm{k}$ & 6.001 & $6.00 \mathrm{k}$ \\
\hline & $\mathrm{T}_{2}$ & $53.00 \mathrm{~b}$ & $53.00 \mathrm{~b}$ & $65.67 \mathrm{i}$ & $65.00 \mathrm{i}$ & $12.67 \mathrm{i}$ & $12.00 \mathrm{~h}$ \\
\hline & $\mathrm{T}_{3}$ & $53.00 \mathrm{~b}$ & $53.00 \mathrm{~b}$ & $70.67 \mathrm{~g}$ & $70.00 \mathrm{~g}$ & $17.67 \mathrm{~g}$ & $17.00 \mathrm{f}$ \\
\hline & $\mathrm{T}_{4}$ & $52.33 \mathrm{bc}$ & $53.00 \mathrm{~b}$ & $67.33 \mathrm{~h}$ & $66.33 \mathrm{~h}$ & $15.00 \mathrm{~h}$ & $13.33 \mathrm{~g}$ \\
\hline \multirow{4}{*}{$50 \mathrm{ml}$} & $\mathrm{T}_{1}$ & $53.33 \mathrm{ab}$ & $53.00 \mathrm{~b}$ & $61.00 \mathrm{k}$ & $60.67 \mathrm{k}$ & $7.67 \mathrm{k}$ & $7.67 \mathrm{j}$ \\
\hline & $\mathrm{T}_{2}$ & $52.67 \mathrm{~b}$ & $51.00 \mathrm{~cd}$ & $75.00 \mathrm{f}$ & $73.67 f$ & $22.33 f$ & $22.67 \mathrm{e}$ \\
\hline & $\mathrm{T}_{3}$ & $51.33 \mathrm{~d}$ & $50.00 \mathrm{e}$ & $78.33 \mathrm{~d}$ & $78.00 \mathrm{~d}$ & $27.00 \mathrm{~d}$ & $28.00 \mathrm{c}$ \\
\hline & $\mathrm{T}_{4}$ & $51.67 \mathrm{~cd}$ & $51.67 \mathrm{c}$ & $76.33 \mathrm{e}$ & $76.00 \mathrm{e}$ & $24.67 \mathrm{e}$ & $24.33 \mathrm{~d}$ \\
\hline \multirow{4}{*}{$100 \mathrm{ml}$} & $\mathrm{T}_{1}$ & $53.00 \mathrm{~b}$ & $53.00 \mathrm{~b}$ & $63.00 \mathrm{j}$ & $62.33 \mathrm{j}$ & $10.00 \mathrm{j}$ & $9.33 \mathrm{i}$ \\
\hline & $\mathrm{T}_{2}$ & $51.00 \mathrm{de}$ & $51.67 \mathrm{c}$ & $81.00 \mathrm{c}$ & $80.67 \mathrm{c}$ & $30.00 \mathrm{c}$ & $29.00 \mathrm{c}$ \\
\hline & $\mathrm{T}_{3}$ & $50.33 \mathrm{e}$ & $50.33 \mathrm{de}$ & $85.33 \mathrm{a}$ & $85.00 \mathrm{a}$ & $35.00 \mathrm{a}$ & $34.67 \mathrm{a}$ \\
\hline & $\mathrm{T}_{4}$ & $51.00 \mathrm{de}$ & $50.00 \mathrm{e}$ & $82.67 \mathrm{~b}$ & $82.33 b$ & $31.67 \mathrm{~b}$ & $32.33 b$ \\
\hline
\end{tabular}

Means having the same letter (s) in each Colum, row or interaction are not significantly different at $5 \%$ level.

\section{CONCLUSION}

IT can be concluding from the aforementioned results, that goat manure + sandy soil $(1: 2, \mathrm{v}: \mathrm{v})$ with $100 \mathrm{ml} \mathrm{EM} \mathrm{is} \mathrm{improving} \mathrm{rooting} \mathrm{offshoots} \mathrm{and} \mathrm{their} \mathrm{growth} \mathrm{characters} \mathrm{of} \mathrm{Hayany} \mathrm{offshoots} \mathrm{date} \mathrm{palm}$ cultivar in the nursery.

\section{References}

[1]. Abd-El-Messeih, W.M., M. Amal El-Seginy and H. Kabeel, (2005). Effect of the EM Biostimulant on Growth and Fruiting of Le Conte Pear Trees in Newly Reclaimed Areas. Alex. Sci. Exchange Journal, 26O2 April-June. Adjusting-controlling soil fertility [J]. Plant Nutrition and Fertilizer Science 9, 406-410.

[2]. Aisueni, N. O. , Ikuenobe C. E., Okolo E. C. and Ekhator F.(2009) Response of date palm (Phoenix dactylifera) seedlings to organic manure, $\mathrm{N}$ and $\mathrm{K}$ fertilizers in polybag nursery African Journal of Agricultural Research Vol. 4 (3), pp. 162-165, March 2009 Available online at http://www.academicjournals.org/AJAR.

[3]. Allan, B. and S. prince, 1965. Absorption and spectrophotometer. Univ., of Hampshire, Durham, Hampshire

[4]. Al-Mana, F. A.; M. A. El-Hamady; M. A. Bacha and A. O. Abdelrahman (1996). Improving root development on ground and aerial date palm offshoots. Principes. 40: 4, 179-181, 217-219; 3 pl.; 11 ref.

[5]. Amro S.M. Salama, Omima M. El- Sayed and Osama H.M. El Gammal (2014) Effect of Effective Microorganisms (EM) and Potassium Sulphate on Productivity and Fruit Quality of "Hayany" Date Palm Grown Under Salinity Stress IOSR Journal of Agriculture and Veterinary Science (IOSR-JAVS). Volume 7, Issue 6 Ver. I, PP 90-99 www.iosrjournals.org www.iosrjournals.org 90 | Page.

[6]. Ayaga G, Todd A, Brookes PC (2006) Enhanced biological cycling of phosphorus increases its availability to crops in lowinput sub-Saharan farming systems. Soil Biol. Bio chem., 38, 81-90.

[7]. Brown, J. D. and O. Lilleland (1946). Rapid determination of potassium and sodium in plant material and soil extracts by flame photometer Proc. Amer. Soc. Hort. Sci, 48: 341-346.

[8]. Easterwood GW, Sartain JB( 1990). Clover residue effectiveness in reducing or thophosphate sorption on ferric hydroxide coated soil. Soil Sci. Soc. Am. J., 54. 1345-1350.

[9]. Elias M. Gichangi; Pearson N. S. Mnkeni and Philip C. Brookes (2009) Effects of goat manure and inorganic phosphate addition on soil inorganic and microbial biomass phosphorus fractions under laboratory incubation conditions Soil Science and Plant Nutrition (2009) 55, 764-771.

[10]. Duncan, D. B., 1955. Multiple range and multiple F Test. Biometrics, 11: 1-42.

[11]. El- Kosary, S.; E. I. Bakr1; I. A. Hussien and A. H Sheren (2008). Effect of the irrigation system and soil components on the growth of date palm offshoots in the nursery. Egyptian Journal of Applied Sciences Zagazig folder 23 Number 8 (b) 602-620) 
[12]. El-Bahr, M. K. (2007). Micro propagation of three Egyptian Date Palm Cultivars. The Fourth Symposium on Date palm, Saudi Arabia King Faisal University, AL-Hassa, 5-8 May. P. 158.

[13]. El-Khawaga A.S., (2013). Effect of anti-salinity agents on growth and fruiting of different date palm cultivars. Asian Journal of Crop Science 5(1):65-80.

[14]. Formowitz, B.; Elango, F.; Okumoto, S.; Miiller, T. and Buerert, A., (2007). The role of effective microorganisms in the compositing of banana (Musa spp.) residues. J. of Plant Nutrition and Soil Sci., 170: Issue 5 pp 649 - 656.

[15]. Hati KM, Mandal KG, Misra AK, Gosh PK, Bandyopadhyay KK (2006). Effect of inorganic fertilizer and farmyard manure on soil physical properties, root distribution and water-use efficiency of soybean in Vertisols of central India. Bioresour. Technol. 16: $2182-2188$.

[16]. Haynes RJ and Mokolobate MS (2001). Amelioration of Al toxicityand P deficiency in acid soils by additions of organic residues: a critical review of the phenomenon and the mechanisms involved. Nutr. Cycl. Agroecosyst., 59, 47-63.

[17]. Higa, T. and Wididana, G.N., (1991). The concept and theories of Effective Microorganisms. In: Parr, J.F., S.B. Hornick and C.E. Whitman (eds.), Proc. First International Conference on Kyusei Nature Farming, US Department of Agriculture, Washington, D.C., pp: 118-124.

[18]. Higa, T., (1991). Effective microorganisms: A biotechnology for mankind. In: Parr, J.F., S.B. Hornick and C.E. Whitman (eds.), Proc First International Conference on Kyusei Nature Farming, pp: 8-14. U.S. Department of Agriculture, Washington, DC.

[19]. Hue NV (1992) Correcting soil acidity of a highly weathered Ultisol with chicken manure and sewage sludge Commun. Soil Sci. Plant Anal., 23, 241-264

[20]. Huphries, E. C. (1959). Mineral components and ash analysis modern methods of plant analysis, edited by K. Peach and U. V. Tracey, Springer Verlag Berlin, 1: 468.

[21]. Ibrahim, W. M. A., (2012). Behaviour of Taimour mango trees to inorganic and organic fertilization and application of EM. Ph. D. Thesis, Fac. of Agric. Minia Univ., Egypt. ISSN 1991-637X (C) 2009 Academic Journals

[22]. Iyamuremye F, Dick RP, Baham J (1996) Organic amendment and phosphorus dynamics: II. Distribution of soil phosphorus fractions. J. Soil Sci., 161, 436-443.

[23]. Jakubus, M., P. Gajewski and Z. Kaczmarek, (2012). Evaluation of the impact of effective microorganisms (EM) on the solubility of microelements in soil. Journal of Zeszyty Naukowe Uniwersytetu Przyrodniczego we Wrocławiu - Rolnictwo, 103(589): 93-102.

[24]. John, J. K. (1970). Colorimetric determination of phosphorus in soil and plant materials with ascorbic acid .Soil Sci., 109: 214-220.

[25]. Lv WG, Huang QW, Shen QR (2005). The effect of organic fertilizer and organic-inorganic fertilizer application on soil enzymes activities during watermelon growing period. Journal of Nanjing Agricultural.

[26]. Osman, S. O.A.; Moustafa, F. M. A.; Abd El- Galil, H. A. and Ahmed, A.Y.M., (2011). Effect of yeast and Effective Microorganisms (Em1) application on the yield and fruit characteristics of Bartamuda date palm under Aswan conditions. Assiut J. of Agric. Sci., 42 (Special Issue) (The 5th Conference of Young Scientists Fac. of Agric. Assiut Univ. May,8, 2011) (332-349).

[27]. Ren ZG, Chen YS, Tang FQ (1996) Effect of inorganic fertilizer combined with organic manure on the microflora and enzyme activities in paddy soil. Plant Nutrition and Fertilizer Science 2, 279-283.

[28]. Snedecor, G.W. and W.G. Cochran (1989). In "Statistical Methods". 7th ed., Iowa State Univ. Press. Ames. Iowa, U.S.A., pp 593.

[29]. Steel, R. C. D. and J. H. Torrie (1980). Reproduced from principles and procedures of statistics. Printed with the permission of C. I. Bliss, pp. 448-449.

[30]. Subba Rao, N.S., (2008). Biofertilizers in Agriculture. Oxford IBH Company, New Delhi

[31]. Sun RL, Zhao BQ, Zhu LS (2003) Effects of long-term fertilization on soil enzyme activities and its role in University 28, 6771.

[32]. Zydlik, P. and Z. Zydlik, (2008). Impact of biological effective microorganisms (EM) preparations on some physic-chemical properties of soil and the vegetative growth of apple-tree rootstocks. Nauka Przyr. Technol., 2: 1, \#4. 